



The Library of the Wellcome Institute for the History of Medicine

MEDICAL SOCIETY OF LONDON DEPOSIT

Accession Number

Press Mark

DOUGLAS, J. 

Arbor Temenfis fructum Cofê ferens:

O R, A

DE S C R I P T I O N

$\AA \mathrm{N} D$

H I S T O R Y

OF THE

\section{COFFEE TREE.}

By Dr. $7 A M E S$ DOUG $L A S$, Honorary Fellow of the Royal College of Phyficians, London: And Fellow of the Royal Society.

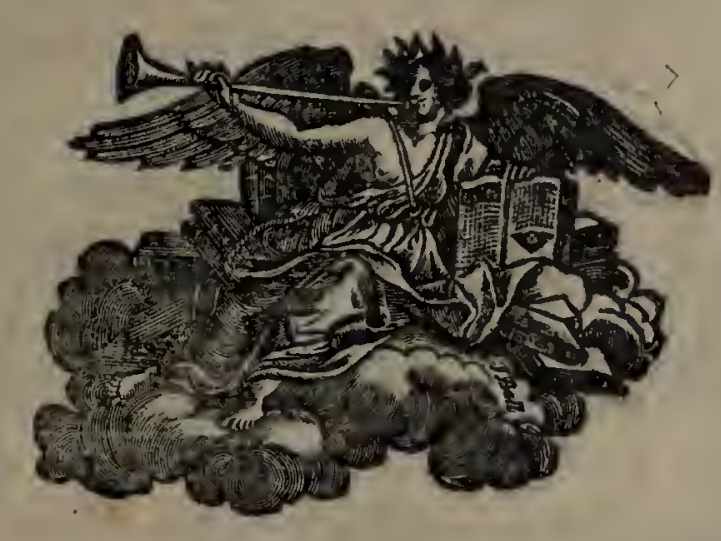

$L O N D O N$ :

Printed for THOMAS WOODWARD, at the Half-Moen over-againft St. Dunftan's Church, in Fleet-ftreet.

M, DCC, XXVII. 


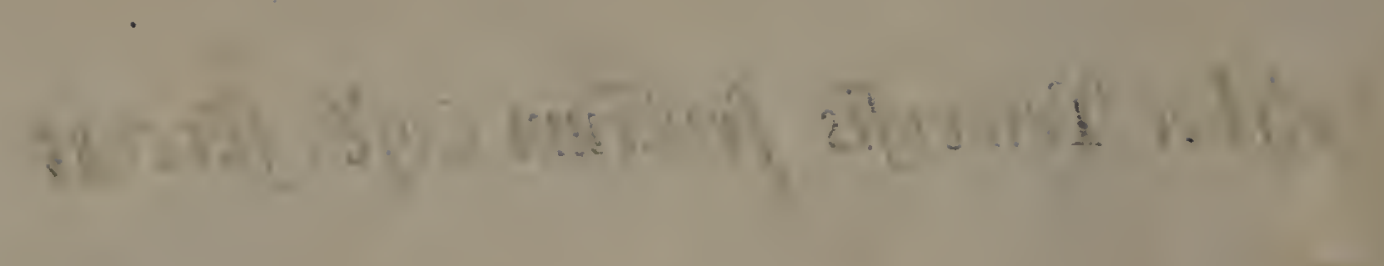

MotT 91 DE TE

I 9 OI I II

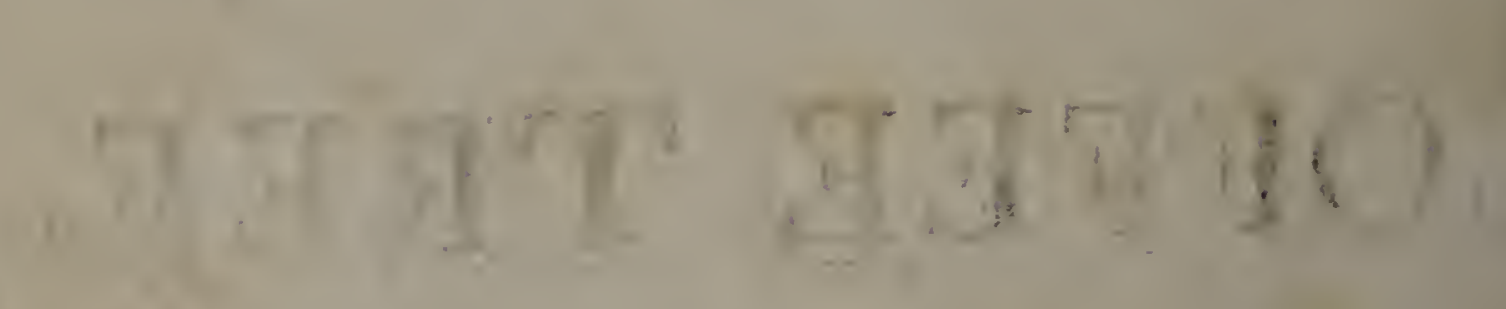




\section{(i)}

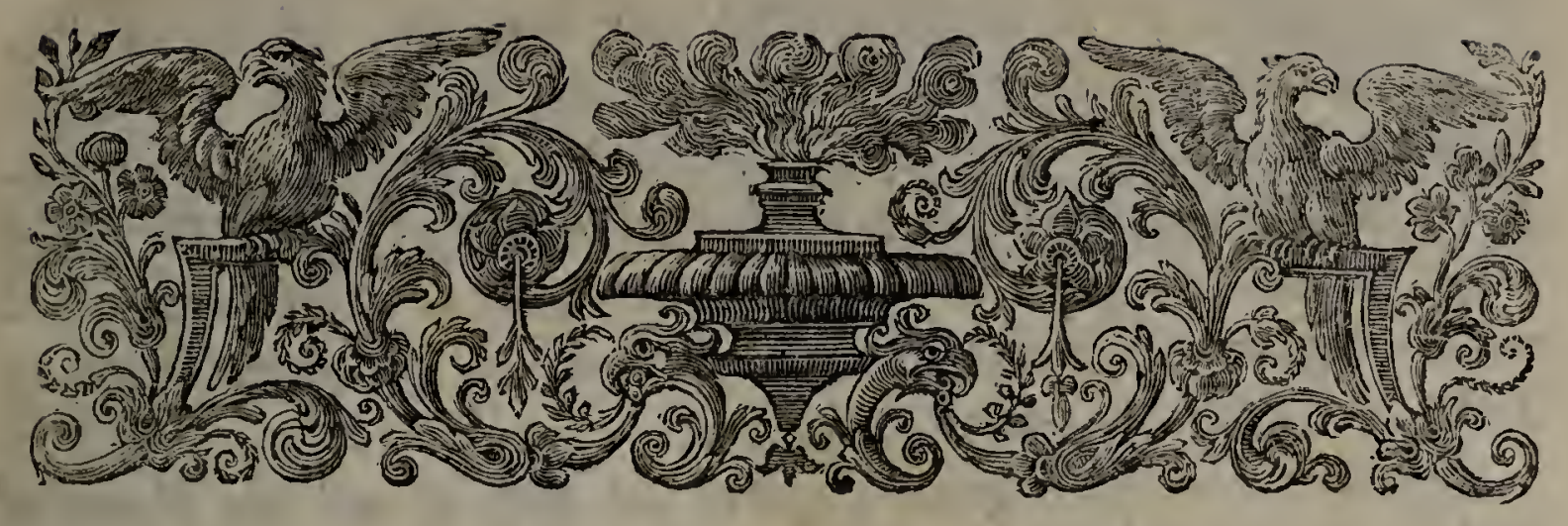

\section{P R E F A G E.}

T $N$ my Botanical Defcription of the Coffee Berry, publifh'd fome Time ago, I acquainted the Readers with my Defign of treating the whole Coffee Plant, as foon 'as I frould have convenient Opportunities of finising the Obfervations about it which I bad then actually begun to make. The Delays and Difficulties I have met with in going tbrough this Enquiry, bave been greater than $I$ at firft apprebended; and I cannot fay I have as yet compleated it to my Satisfaction; bowever, what I now venture to communicate, will, I bope, in fome meafure gratify the Curiofity of the Publick, and be of fome real Ufe to thofe who bave any Defire and Opportunity of cultivating this delightful Exotick, of the Fruit whereof there is yearly made fo vaft a Confumption among us.

I begin by a Lift of Names that belong to this Plant, and baving made fome neceffary Reflections upon thefe, I give a large Account of the Loci Natales, or Places wherein it is at prefent found to grow, as well in the Kingdom of Yemen in Arabia Felix, as the other Countries both in Afia, Europe and America, tbro wibich it has now Spread it Jelf, Jetting down what Informations I bave been able to get concerning every Step of its Progress. fince it firft found the $W$ ay out of its native Country. Having in the next place premised fome general Obfervations about the Plant it Jelf, as it bas been confider'd by Botanical Writers, I go on to a particular Defcription of all the Parts of it, taken from my own repeated Obfervations, carry'd as great a Length as it bas bitherto been in my Power to do; and I conclude by fuch Direc- 


\section{(ii)}

tions concerning the Culture and Management of it, as I cons ceive can be of any Service to us here in England.

Upon each of the fe Heads I have been at Pains to collect what has been faid by Authors before me; and befides the biflorical. Facts which I fet down from them, I bave taken the $L i$ berty to compare their Obfervations about the Plant it felf with mine, as well to point out their Miftakes, as to explain the particular Difcoveries made by each of them, in the fame Order of Time in which they were publifbed.

$I$ propos'd to bave given Figures not only of all the Parts of a full grown Plant, in an agreeable Variety of infructive Views, but alfo of the Several States of it, from the Time it firft appears above the Surface of the Earth, both with respect to Age, and the Seafons of the Year; but as I bave not as yet been able to perfect thefe in any tolerable Degree, I chufe to refer them altogether till fome more bappy Opportunity Sall offer; and then, together with a compleat Set of Figures, I Sall be likewife in a Condition to lay before the curious Reader the Hiftory of the Invention and Progress of the UJe of the Coffee Drink, both in Afia, and in the Eaftern and Weftern Parts of Europe; of the Several Methods in which it has been prepar'd fince it was firgt known; of the firf Inftitution of Coffee Horses, and of the Virtues zubich either Opinion or real Experience bave afcrib'd to it. I eurnegly bey of alt curtous Perfosss to impart to me what Memoirs they may be furnifh'd with relating to any of these Particulars, and I Sall moft willingly acknowledge the Favour in the Way I judge will be moft agreeable to them.

I conclude by returning my moft fincere Thanks to thofe learned and worthy Friends by whom I bave been in any meafure afjifted in the Profecution of the En Eniries; and among the reft, I muft acknowledge my felf in a particular Manner obliged to thofe two curious Gentlemen, $M r$. PAR KE R of Heling, and $M r$. SHERRARD of Eltham, to whose invaluable Gardens I had at all times free Access, whenever I found it neceffary to view the Coffee Plants, which have continued for feveral Years to thrive there beyond Expectation; every Seafon bringing them a new Acceffion to their former Stock. 


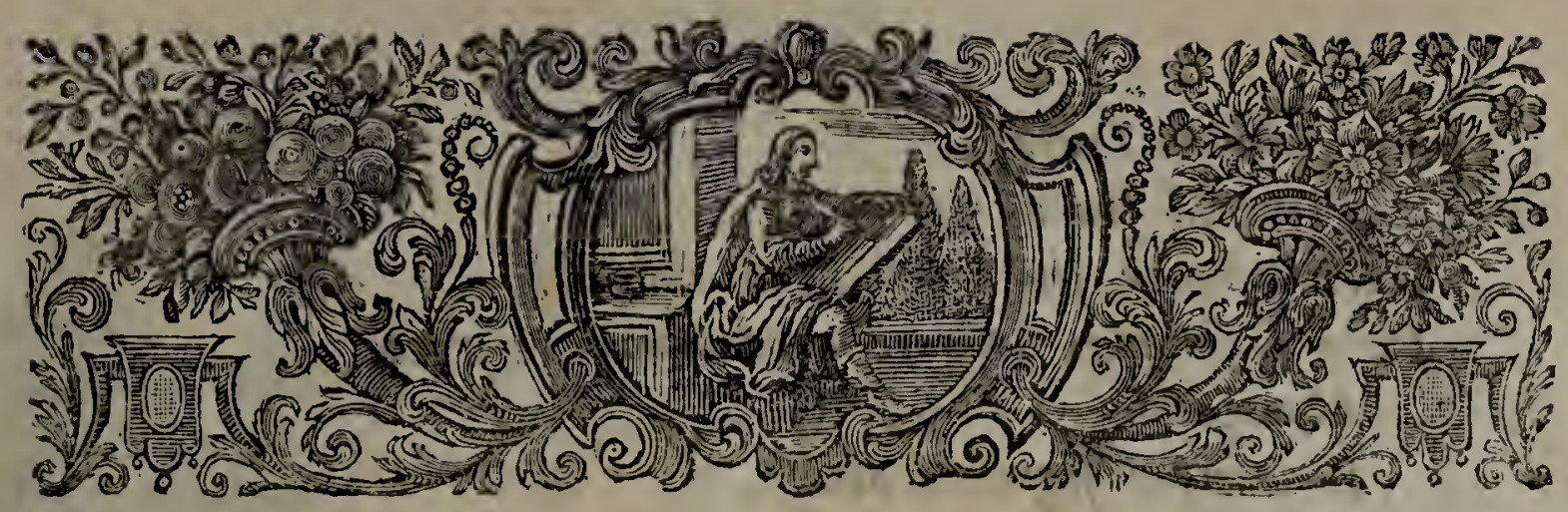

\section{DESCRIPTION}

OF T H E

\section{COFFEE TREE.}

\section{H $\triangle$ A P. I.}

\section{The Names of the Coffee Plant.}

7HE Names that have been given by Authors to this Plant,

to particular Parts of it, and to Preparations of thefe Parts, I thall diftribute into three Lifts: The firft, containing thofe of the whole Plant; the fecond, thole of the Fruit; and the third, thofe of the Liquor made with this Fruit: And I chofe to place all thefe three forts of Names inmediately after one another, that it may be more eafy for thofe who indulge themfelves in fuch hiftorical Curiofities to compare them together, in the manner that they will find done in the following Chapter, or in any other that they thall think convenient.

The whole Coffee Plant taken together, inay, I think, be exprefs'd very juftly in the following manner. The Botanical Reader will not be furpriz'd to find this Name in Latin; nor will the Length of it be judg'd unfuitable to the Cuftom of Authors in that Science, on the like Occafions. 
Arbor Arabica Yemenfis,

\section{$(2)$}

Perpetuâ fronde virens.

Folio Caftanee feu Lauri baud abfinili.

Flore Fafminum vulgare quodammodo referente.

Monopetalo,

In quinque fegmenta divifo,

Albo,

Odorato.

Vafculo Seminali, ut plurimum, bicapfulari, nonnunquam tricapfulari, in fructum nuciformem abeunte;

E. cujus nucleis, potus ille faluberrimus Coffee vulgo dictn:s paratur.

Or fhorter, after this manner,

Arbor Yemenfis fructum Coffee Ferens.

I. The Names which have been hitherto given to the whole Plant, and which may be reckon'd fynonyma to that which I have pitch'd upon, are thefe.

Bon zel Ban Arbor.

J. B.

Euonymo fimilis Egyptiaca, fructu baccis Lauri fimili.

C. B.

Arbor Bon cum fructu fuo Buna.

Parkins.

Bura Alpini.

Chabr.

Café.

Bernier.

Bon vel Ban,

Bonchum, Buncho, Buncha,

Elkarie Egyptiorum,

Blegny.

Cacbua Arabum.

The Coffee Tree.

Plunkne?

Coffee Frutex ex cujus fructu fit potus.

Raii.

Coffee Arbor.

Dale.

Coffee Shrub.

Sloane.

Arbre. 


\section{(3)}

Arbre du Buun.

Arbre qui porte le Café. $\}$

Galand.

Arbor Perfica.

Filix Arabica.

\section{Lang.}

Bannu \& Banchos Arabum.

Caffé ou Coffé.

Tournef.

Fafminum Arabicum, Caftanex folio, flore albo, odora-? tifimo, cujus fructus Coffy in officinis dicuntur nobis.

Fafminum Caftanee folio, flore odoratiffmo, rubro fructu qui Coffé, duro.

Commelin.

Gelfiminum Arabicum foliis Caffanes, flore albo ingenti? odoratiffrmo.

Arbor cofè ferens.

Volkam.

L'Arbre du Café ou Cafier.

Fafminum Arabicum Lauri folio cujus Jemen apud nos Café dicitur.

De Juffieu:

Fafmin d'Arabie, a feuilles de Laurier, \& dont la femence nous eft connu fous le nom de Café.

Arbor Meccana.

Cheyn.

II. Names of the Coffee Fruit.

Bunnu.

Buncho Avicennx.

Rauwolf.

Buncha Rhazis.

?

Bon vel Ban.

Alpin.

Bund.

Iilcane.

Clus.

Buncha Rhaz. ex Rauwolf.

Cachu. 


\section{(4)}

$\left.\begin{array}{l}\text { Cacbu. } \\ \text { Buncbi. }\end{array}\right\}$

Cotovic.

Bunchos.

Bunnum Rauwolf.

J. B.

Granum quo Turce fomnum fugant Plater.

Cabrué.

Lavalle.

Coffee.

Cophié.

Ruinfey.

Copby.

Coffé.

Ben \& Bun.

Banes.

Elcave.

Salmar.

Coffee Berry.

Grew.

Coffa.

Mundy.

Café.

Bernier.

Caboueb Arabum.

Du Four.

Caveb Turcarum. $\}$

$\left.\begin{array}{l}\text { Bacce Coffee. } \\ \text { Cobo Seeds. }\end{array}\right\}$

Coffee, in Latin Coava.

Boncha.

Boncho.

Elkarie.

Semen Coffee.

Pechey.

Pomet.

Berlu.

Herman.

Bunn. 
Bunn.

Galand.

Terris faba miffa Pelafgis.

Vanier.

Coffi.

N. Lemer.

Coffee Bebnen.

Lang.

Caboven.

Volkam.

Cofea.

Quincy.

Faba Meccana quam Coffeam rocant,

FruCtus Arboris Meccane.

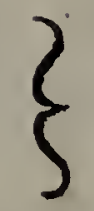

Chyne.

III. Names of the Liquor or Drink prepared with the Coffee Fruit.

Chaube.

Caova.

Choana.

Cave.

Cabua, Carva Italor.

Coffa.

Cabué.

Cabwe.

The Turks berry Drink.

Caffé.

Cophie.

Turks Pbyjick of Cophie.

Copby.

Coffee.
Rauwolf.

Alpin.

Paludan.

Bellon:

Cotovic.

Sandys:

Lavalle:

Olear.

Parkins.

Tavernier.

Rumfey.

$c$

Cabrwa. 


\section{(6)}

Cabra.

Pauli.

Cabue Jeu Café.

Banes.

Coffe potus:

Willis.

Café.

Bernier.

Cavet.
Cabue.
Choana.
Cabreb.

Du Four.

Couphe.

T. Blount.

Coava.

Caphé. $\}$

Blegny.

Coffi:

Bontekoe.

Gabouab Arab.

Galand.

Gaoube Turcarum

De Jufieu.

Goffé. Anglorum \& Batarorum $\}$

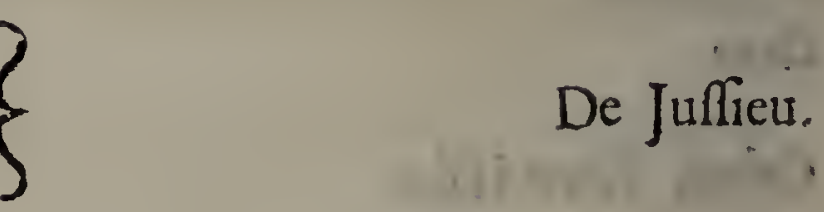

*120.

aticisol I

$\because=10$

sidis?

.19iment?

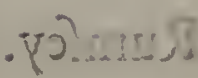

CH A P. 


\section{( 7 ) \\ C H A P. II. \\ Etymologia.}

DY thefe Names, and no more, that I can find, have the 3 Coffee Plant, the Fruit thereof, and the Liquor made with that Fruit, been expreffed. The Lifts I have here given of them, tho' they cannot I believe be of much folid Ufe, may perhaps entertain the Curiofity of fome of my Readers; and fince I have been at the Trouble of collecting them merely with that View, it will be ftill worth while to add the few following Obfervations about them.

I. Tho' fome of thefe Names are common to the whole Plant, Fruit, and Liquor; there are many which are either peculiar to each, or which belong only to two of them; and therefore it was moft natural to feparate them into three diftinct lifts, inftead of throwing them all into one confufed heap, as has been the general practice of Botanifts hitherto. Mr. Ray fhall ferve for an Example of this.

The Name he gives the Plant, is this, Coffee frutex ex cujus fructu fit potus.

The Synonyma or Names he fets down from other Authors are thefe.

Bon vel Ban Arbor, J. B. Item, Buna, Bunnu, Bunchos Arabum ejufdem. Bon Arbor cum fructu fuo Buna, Park. Euonymo fimilis Egyptiaca fructribaccis Lauri fimili, C. B. Bunnu, Rauwolf. Buna ex qua in Alexandria fit potio, Clur.

Never was there a Lift of Synonyma compiled with lefs Judgment than this; for in the firlt place, it is defective by. above four parts in five, as will appear by comparing it with mine; and Defects of this kind are more inexcufable in Mr. Ray than in any body elfe; for as he has done little any where but collect from other Authors, the leaft that could be expected from him, is, that his Collections fhould be perfect, after fo many Years Practice.

Again, the Order of Time, in obferving which with Exactncls, the greatelt Beauty of fuch Compilations certainly confifts, is entirely neglected; Rawwolfuis and Clufus are placed after the rwo Baubini and Parkinfon.

But, which is moft to my prefent purpofe, above half his Synonyma are falle, $\mathcal{F}$. $B$. never called the Coffee Plant Buna, 


\section{(8)}

Bunnu, Bunchos Arabum; Rauwolfus never called it Bunnu; nor Clufius, Buna. It is the fruit only they have expreffed by thefe Words, and never the Tree that bears it; and yet Mr. Ray has thought fit to rank them all as fo many Synonyma for his Coffee frutex, that is, as Names given by thefe Authors to the whole Plant.

Later Botanifts have been fo far from not falling into this laft mentioned Inaccuracy of Mr. Ray, that they have carried it a grear deal further. This Author has only confounded the Names of the Tree and Fruit: but in another, I find the Coava Egyptio. rim from Alpinus, placed as a Synonymum for the Fafminum Arabicum, Ecc. of Commelinus; that is, a Name never applied by Alpinus to any thing but the Coffee Drink, made to fignify the Tree which produces the Fruit of which that Drink is made.

2. That we may be able to take a more particular View of the Names contained in the three foregoing Lifts, it will be convenient to fubdivide each of them into fuch as Travellers tell us are ufed in the Eaftern Countries, and thofe which the Europeans have either borrowed from thence, or invented of their own, fince Coffee was known amongit them.

As to the firt of thefe, I am furprized to find that no Traveller, except. Monfieur Galand alone, has given us any Name by which the Coffee Plant it felf is expreffed by the Arabians, or any other Eaftern People: The whole Lift we have given of thefe Names, except that of the Bunn Tree, from Galand, has been coined in Europe, by thofe who knew nothing of the Plant, but only that it produced the Coffee Fruit; and they who have expreffed it otherwife than by fuch a Circumlocution, have only difcover'd their own Ignorance, and the little Care with which they have read the Bcoks of Travels quoted by them. Chabreus, Blegny and Langius, are of this number; but $\mathcal{F}$. B. and Parkinfon, who likewife ufe Oriental Words in expreffing the whole Plant, have kept within due Bounds.

3. The Eaftern Names of the Fruit, are either fuch as have fome Relation to Bunchum, Bon, or Cabouab.

The firft Kind, tho' there be perhaps fome of them that are really Oriental Words, as Bunchum its felf is, are not however to be reckon'd Eaftern Names for the Coffee Fruit; becaufe they have only been apply'd to that upon the Suppofition of its being known to Rbazes and Avicenna, and called by them by the Name of Buncbum, or fomething like it, which we fhall thew to be a Miftake. Two Perfian Phyficians were undoubtedly the firft who fell into it; but it is from Rauwolfus that it has been handed down among European Writers. 


\section{(9)}

Bon, or rather Bunn, and the other Names which confift of the fame Confonants with it, feem to be thofe by which the Fruit has been moft generally expreffed in the Eaft; but whether fome part of the Variety that is to be found in them may not be owing to the Miftakes of Travellers, I leave to the Judges of the Eaftern Languages to determine. Salmafus has, I think, given us one plain Inftance of it in Alpinus, and Monf. Galand, (if we will believe $\boldsymbol{L} a$ Roque) another in Banefius, tho' a Syrian by Birth.

The third Sort of Names for the Fruit, we fhall confider together with thofe of the Liquor, they being derived from thence:

4. Concerning thefe, the following Remarks from Authors are worth fetting down.

' It will hardly be believed, fays Monf. Du Four, that tho' Cof- fee has been drank for fo many Years paft, we fhould ftill be - ignorant of the true Name of it. The Authors who have - written upon this Subject differ from one another as much in ' the Names they give this Liquor, as in the Qualities they afcribe ' to it. Some tell us that before it be ground it ought to be cal' led in Latin, Bunchum; and in French, Bon; which they pro' nounce, Bun. After it is reduced to Powder, there are a great ' many other Names given it, which have been already fet down.) - But Monf. D' Arvicuse, the French Conful at Aleppo, who had ' Jeen at great pains in inform himfelf while he remained there, " tells me that the true Name of the Coffee Bean, among the 'Arabians, is Caboueh, the Arabians having no $v$ Confonant; - but the Turks, and other Eaftern Pcople, pronounce it Cabveh; ' and that Word is derived from Cobuet, which fignifies Strength " or Vigour; and the Coffice Fruit is fo called becaufe of the Ef- feets afcribed to it.

This Etymology did not, however, farisfy Monl. Galand; as appears from the Account that $L a$ Roque has given us of that Part of his Book. ' Monf. Galand, fays he, begins by eftablinh' ing the original and proper Signification of the Word Coffee; ' and according to him it comes from Cabveh, as it is pronounced ' by the Turks, with an $v$ Confonant; and it is the fame thing ' with Cabouah, amongtt the Arabians, who pronounce their $v$.

' Confonant as the Italians do their Vowel $u$.

' Cahouah is the Infinitive of a Verb, and fignifies to loath,

' or to have no Stomach; and it is likewife one of the different

- Names which the Arabians give to Wine, becaufe they think - the Excefs of it produces thefe bad Effects. 


\section{( IO)}

From this Signification of Wine in particular, the Word Cas bouah has been extended to all forts of Drink; and therefore this Word is not ufed either for the Tree or Fruit, but only for the Drink made of it.

The Fruit is called Bunn; and the Tree, the Bunn Tree.

Monf. Galand goes on to remark fome Miftakes of Banefrus ; and then adds, That if that great Profeffor could be miftaken in ; his own Language, it is but juft to excufe Monf. Du Four's Friend, who fays that Cahoueh is the Arabick Word for the Coffee Fruit; which is rather a Turkish Pronunciation than Arabian, fince there is no $e$ in their Alphabet. Moreover, that Gentleman has confounded the Term Caouä, with that of Cabouab; tho' they are both written and pronounced very differently.

If this Account of the Original and true Signification of the Word Cabouah be juft, as there is no Ground to doubt of either, confidering both the extraordinary Skill of that Author in the Oriental Languages, and the long Stay he made in the Eaft; we need be at no Lofs what Judgment to make of all the Eaftern Names that have been given to the Coffee Drink; they may all be eafily derived from the Arabick, Cabouah; and the Variety that is to be found in them is owing either to the real Changes they have undergone in the Mouths of the different Eaftern Nations, Perfians, Egyptians, Turks, \& c c. or to the Miftakes of Travellers, moft of whom being ignorant of thefe Languages, have not always equally well expreffed, in Writing, the Sounds by which they heard this Liquor fignified in the different Countries of the Eaft. Neither are fuch Miftakes to be wondred at, confidering how common they are even among the different Nations of Europe at this Day; whofe Languages have a nearer Relation to one another, than the Eaftern Languages have to any of them. Let a French Man, for inftance, hear forty Englifs Words diftinctly pronounced one after another, feveral times over, it is forty to one at leaft, that he does not write two of them right. There are Examples enough of this in all the French Writings, where there is occafion to mention any Englifs Words; and we have one in the foregoing Lift. Monf. De Fuffeeu tells us very gravely, that both the Englijh and Dutch call this Liquor Coffé: with a fingle $e ́$ accented; only for this Reafon, becaufe he has heard the Word Coffee pronounced nearly the fame way as a French Man would do, had it been fpelt after his manner.

From Monf. Galand's Etymology we learn likewife, that all the Words by which the Fruit it felf has been fignified, that have any Refemblance to Cabouah, which make the third Clafs of the 


\section{( II )}

Eaftern Names of it, are not to be looked upon as fuch, being never ufed in that Senfe by the Orientals.

5. From thefe Eaftern Names are derived thofe by which all the European Nations do ordinarily exprefs both the Coffee Plant, Fruit and Liquor. As we had the firt Knowledge of thefe things from them, it was natural to take their Names along with them, and only by degrees new mould them a little, according to the Genius of each particular Language into which they were adopted.

The Turkifs way of pronouncing Cabouah, viz. with an $v$ Confonant, as we have heard, occafioned firlt the writing of it here in England with $p h$, and afterwards with $f f$; which is equivalent thereunto. The $c a$ we find changed into $c 0$, in Sandy's Time; $i . e$ in the Year 1628, in which his Travels were publifhed; and it was near the Year 1659 , that is, feveral Years after there were publick Coffee-houfes in London, before the Termination ee was fully fettled; for we find Judgc Rumfey and Sir Henry Blount writing this Word fometimes with ie, fometimes with ee; but Howel always ufes the latter; and it has continued ever fince his time. Sir Thomas Pope Blount writes it fometimes cauphe, having found it fo written, probably, in fome old Book: From whence there is ground to conclude, that the Turkifs ca was firft changed into cau, which being pronounced pretty much the fame way as co, this laft, as being fhorter, came at length to be ufed inftead of it.

Variations of the like kinds, and by the like degrees, may be obferved, no doubt, in the other modern European Languages: But it is not our prefent Bufinefs to enquire further into them.

As Coffee was unknown during all the time in which the Latin can in any Senfe be faid to have remained a living Language, we are not to expect any true Latin Word for it : To fupply that Want, Authors who affect to find Latin for every thing, how much foever unknown to the Latins themfelves, have had Recourfe to the two univerfal Engines, which are always ready in time of Need, viz. inflecting the laft Syllable of this Word into a Latin Termination, and expreffing it by long Circumlocutions, which ought rather to be called Defcriptions than Names. Of the firft kind is the coffea, $\mathscr{e}$, of Dr. Quincy, and the coava of Pechey. The former is allowable enough, had there been any Neceffity for it; but the other is owing either to the Stupidity of its Author, or ufed with a Defign to impofe on the Reader: For what can be concluded from thefe Words, coffee is in Latin, Cûnin; but either that Pechey took coava for a genuine Latin Word himfelf, or had a mind to perfuade other People that it was fo? 


\section{( 12$)$}

It is needlefs to enumerate the various things that have been made ufe of by Authors, as a Foundation for the Circumlocutions by which Coffee, and efpecially the Coffee Plant, has been expreffed: It is fufficient to remark, That thofe moft in Vogue now-a-days have been taken from the Agreements obferved therein with thefe Parts of the Jeffamins which Botanifts principally attend to in diftributing Plants into Claffes, Sections, Genera, Esc. by this means $\mathrm{Fafminum}$ is become the generical Word for it; and the reft of the Circumlocution is only a Catalogue of Differences by which it is diftinguifhed from the other Species of Plants ranked under the fame Genus with it; or a fort of Defcription of what is thought to be moft remarkable in it.

\section{H A P. III.}

\section{Locus Natalis.} $\mathrm{T}$ would be to no Purpofe to take Notice of all the Miftakes
that both Botanifts and Travellers have been guilty of in determining the Countries where Coffee grows: Some have brought it from India, others from Perfia, others from Egypt, and a great many from that Country of Arabia where Mecca is fituated; but it is now paft all Difpute, that Coffee grows no where in Arabia, but in the Kingdom or Province of Yesnen, in Arabia Felix; nor any where elfe in the World, except in the Inlands of Fava and Bourbon, and fome other Places where it has begun of late to be cultivated by the Induftry of the Dutch, French and Englifh; of which in the proper Place.

This Kingdom of Yemen, as all the other Parts of the valt Territories of Arabia, is ftill too much unknown for the Reader to expect any particular Account of it; Monf. De Lifle has been at all poffible Pains to give us an accurate Map of fo much of it as he could get any tolerable Informations about, either from the European and Arabian Geographers, or from the French Offcers who were upon the two Expeditions lately made from St. Malo's to Moca; of which Monf. La Roque has given us a very compleat Relation; yet even that is very imperfect.

However, that I may not leave my Readers altogether uncquainted with the Country to which all the World is beholden for the Fruit which I am now defcribing, I have thought it pro- 


\section{( 13 )}

per to infert here a flort Abstract of a Journey from Mocca to the Court of the King of Yemen, undertaken by fome Perfons in the fecond of the forementioned Expeditions; and likewife publifhed by Monf. La Roque.

The two Veffels of which this fecond Expedition confifted, arrived at Mocca on the $\mathrm{I}^{\text {th }}$ of December, $17^{1} \mathrm{I}$; and foon after, the King of Yemen, of which Country Mocca is now the principal Sea-Port, fell fick. His new Minifter, who at the time of the former Expedition had been Governor of that Place, extolled the Skill of the French Phyficians, and advifed him to fend for thofe that he heard were lately arrived. The King confented, and charged Cheick Saleb himfelf, (that was the Minifter's Name,) with this Affair; who thereupon immediately difpatch'd two Deputies to the French Captains, with a very obliging Letter, fignifying the Subject of their Commiffion.

The Captains, after fome Deliberation, concluded at laft that this was a fit Opportunity to thew the King fome Samples of the Grandeur of France, and to difcover as much as they could of the Country to which they were then eftablifhing a Trade. Hereupon the proper Perfons were pitched upon; and having receiv'd their Infructions from the Commanders, and likewife fome Prefents for thie King, they left Mocca, well mounted on horfeback; the $14^{\text {th }}$ of February, $1711-12$. Their whole Company confifted of about twenty Perfons, under the Guard of a Troupe of Horfe, their Baggage and all Neceffaries for their Journey being carried by Camels, and other Beafts of Burthen:

They fet out about four a Clock in the Afternoon, and travell'd all the reft of that Day, and a good Part of the Night, and about three in the Morning they arrived at Mofa, a little Country Town ten Leagues diftant from Mocca.

The next Day they travelled fifteen Leagues, to Manzary, where there being only fix or feven Houfes, they paffed the Night under Palm and Poplar Trees.

For eighteen Leagues further the Roads were exceeding good, the Country being almoft one continued Plain, at the End of which lies Tagus, a Town much renowned amongft the Inhabitants, and ftrongly walled, with a Caftle which commands the whole Town. The Governor was Son to the late King, and the Deputies did not fail to pay him their Refpects. He received them very civilly, and treated them, amongtt other things, with Coffee, a la Sultane; a Drink made of the Involucra of the Fruit only, and much in Requelt all over that Country. 


\section{(14)}

From thence they continued their Journey towards Manrael; and about fix Leagues from Tagus they had the Pleafure of feeing Coffee Trees for the firlt time; and thefe pals for the moft beautiful and beft cultivated in all remen.

Manzuel has nothing remarkable; and from thence they went in two Days to Tram, lying the firf Night under the Trees.

After they left that Town, they found the higheft Mountains which are in the Kingdom; and the Country, which till then was pleafant enough, tho' moftly mountainous, began to be dry and barren; no Trees were to be feen there, nor Valleys full of. Coffee Plantations, as they had hitherto frequently met with.

From Yram, they went to Damar, another confiderable Townat fifteen Leagues Diftance. The Roads were uneafy, and the Heat exceffive, till after Sun-fet.

At Damar the Scene changes again, and a very fine Country begins to open. Muab, the Refidence of that King, is but a quarter of a League from thence, and the Deputies arrived there the eighth Day after they left Mocca; having travelled above an hundred and twenty Leagues almoft conftantly to the North Ealt.

Their Reception, and all that befell them during the three Weeks they remained there, I leave to be confulted in the Author, there being but little of that which has any Relation to my prefent Defign.

The Town of Muab is remarkable for nothing but the Prince's refiding there. One of the Suburbs is wholly inhabited by Fews, who are never allowed to lie within the Gates. The Air is very good. Between nine in the Morning and four in the Afternoon the Heats are great; but it is pretty cool both before the rifing and after the fetting of the Sun.

The Soil about the Town appear'd every where very good. All the Plains were fown with Wheat and Rice; and the little Hills and Valleys were planted with Coffee Trees, Vines and Fruit Trees.

There was nothing remarkable in the King's Gardens, except the great Pains taken to furnifh it with all the Kinds of Trees that are common in the Country; amongft which there were Coffee Trees, the finelt that could be had. When the Deputies reprefented to the King how much that was contrary to the Cuftom of the Princes of Europe, who endeavour to ftock their Gardens chiefly with the rareft and moft uncommon Plants that can be found. The King returned them this Anfwer, That he valued himfelf as much upon his good Tafte and Generofity as any Prince in Europe; the Coffee Tree, he told them, was indeed very 


\section{( 15 )}

common in his Country, but it was not the lefs dear to him upon that account; the perpetual Verdure of it pleafed him extreamly; and alfo the Thoughts of its producing a Fruit which was no where elfe to be met with; and when he made a Prefent of that that came from his own Gardens, it was a great Satisfaction to him to be able to fay that he had planted the Trees that produced it with his own Hands.

The Kingdom of Yemen is not hereditary, but he that has had the Art of making himfelf the Atrongelt Party during a King's Life, is commonly his Succeffor; and the King takes all poffible Care to gain every Body in Favonr of his Children or neareft Relations.

The King is independent, being tributary to no other Prince; and as a Proof of that, while the Deputies remained at Monab there arrived Ambaffadors to him from the Grand Seignior. It was given out that it was only an Embaffy of Ceremony and Compliment; but the true Reafon was to perfuade the King, not to allow the Europeans the Liberty of exporting Coffee by the Red Sea directly, which was a great Lors to the Turks.

The King being at length perfectly recovered, the Deputies took Leave of that Court, and returned to Mocca; they came back the fame Way they went, but not being in fo great a Hurry, they had more Time to make Remarks concerning the Country.

The greateft Part of the Mountains are barren, being burnt up by the Heat of the Sun. They produce no great Trees, but upon the lower Sides of them there are Plenty of Coppices. They met with red Partridges bigger than ours, Quails and Turte Doves in abundance, which the Arabians never offer to fhoot. The Foxes and Monkeys were fo tame, that let a Man go as clofe to them as he plealed, they never offered to run away.

But the greateft Curiofity of our Travallers, upon their Return, was to obferve every thing that relates to the Coffee Plantations, and to inform themfelves of the Arabians concerning them.

Befides the Coffee Trees, there were to be feen in the fame Plantations with them, a great many other Sorts of Fruit Trees, fuch as Peaches, Apricocks, Almonds, Citrons, Oranges, Figs, Apples, \&c.

They were informed, that befides the Towns which they faw, there were others of very great Note, amongft which is Sanaa, formerly the Capital of the whole Kingdom, and the Seat of their Kings. There are likewife feveral of the great Roads of the Kingdom paved for above an hundred Leagues together. 


\section{(16)}

Thefe are the Particulars contain'd in this Relation; which may ferve to give at leaft fome generat Notion of the Country which produces Coffee. The true Extent of it is not as yet known; and much lefs in what Parts of it Coffee Trees grow, or how much Land is yearly employed for thefe Plantations. Mr. Bradley tells us, that the greateft Part of them are a few Days Journey inland from Mocca, and near the City Sanaa, about twenty Degrees of Northern Latitude. And in another Place, that the Coffee Tree is found from the Latitude of eighteen to twenty Degrees North.

We fhall hear fomething more determinate about this from $\mathrm{Mr}$. De la Morveille, in what he has faid about the Coffee Trade. But as the Coffee Plant has now; notwithiftanding all the Pains the Arabians have been at to prevent it, found its Way to other Parts, and is there cultivated with good Succefs; an Account of the Manner in which that happened, and what have been the Confequences thereof, belongs likewife to the Hiftory of the Locus Natalis of this Plant. And here I muft begin by obferving, that by a late Account fent to Mr. De Fufieu at Paris, from one Mr. Gaudron, an Apothecary at St. Malo's, publifh'd in the Hiftory of the Royal Acadeniy, it would feem that the Coffee Plant, or at leaft one Species of it, was a Native of the Ifland of Bourbon, near Madagafcar, as well as of the Kingdom of Yemen.

- The Inhabitants of the Inland of 'Bourbon, fays Mr. De Fontenelle, ' having feen fome Branches of the Coffee Tree, fuill of - Leaves and Fruit, which a French Veffel had brought from ' Mocca, prefently difcover'd that they had the fame Sort of ' Tree growing upon their Mountains; and upon comparing ' them together, the Ships Company were convinced that they - were really alike; only that the Bourbon Coffee Fruit is longer, - fmaller, and greener than that of Arabia, and when burnt has ' a bitterer Tafte.

Whatever Way this Plant got into that Ifland, it is certain that the French, to whom it belongs, have lately cultivated Coffee there with good Succefs, and have fent feveral large Quantities into Europe; and it is not long fince the publick News-papers gave us an Account of the Sale of one Parcel by the French Eaft India Company at Paris, which was faid to be as good as any thar comes from the Lervant. Tho' we fhould fuppole this an indigenous Plant of that Illand, yet it has been fo lately known there, and that only by comparing it with others brought from Arabia Felix, that had not a Way been found of propagating it from 


\section{(17)}

this Country, Europe might Atill have been without it; and the Curious might ftill have had Reafon to complain in thefe elegant Words of Mr. Ray, Mirun tantum The faurum unius gentis, peculium effe, tamque lucrofe firpis Plantaria, intra unius Provincia Anguffias coërceri. Mirum vicinas Nationes extimulante invidia aut avaritia, ea jam pridem non vel vi depopulatas effe, vel femina aut vivas radices dolo furripuiffe. Mirum quem vigilem draconem Coarvetis fuis tuendis preficiant indigene, qui omnes infidiantium technas, \& conatus fruftretur \& eludat. But now, by the Care and Induftry of the fagacious Dutch, the Ground of that Complaint has ceas'd, Delufe jam vigilantifimi Draconis Arabici techne, Arborque non tantum in alias Afraticas tranfplantata nunc Regiones, Jed \& in Europam noftram tranfvecta, latì nunc in Belgio es Septentrionalibus Oris, accedente indefeflis culturce curis virefcit. As Volkamerus has well expreffed it.

How the Duich made themfelves Mafters of the Coffee Plant, has been variounly related by Authors: Some are of Opinion, that they found Means to carry off a whole Tree by Stratagem; and Mr. Bradley, amongt the reft, has related a Story to this Purpofe. But it is from Profeffor Boerbaave that we learn the whole Truth of this Matter; and likewife by what Means the Plant was brought into the Amfterdam Garden. Nicholas Witfen, Burgomafter of Ainfterdam, and Director of the Dutch Eaft-India Company, wrote feveral times to M. Van Hoorn, then General of Batavia, to caufe fome frefh Coffee Seeds to be brought from Mocca; and to be planted and cultivated with all poffible Care in the ifland of fava, of which Batavia is the Capital. Van Hoorn did as he was directed; and having in a little time rais'd a confiderable Number of Plants, he fent one of them to Amfterdam, in a Prefent to Witfen, who, as he had been the original Founder of the Phyfick Garden there, thought that the moft proper Place for it to be lodg'd in. There it foon bore Fruit, from which many new Trees have already and ftill continue to be raifed. This Relation that learned Author affures us he had from Witfen himfelf; but his original Words, of which I have here given the Subftance in Englis, deferve to be fet down: Ampliffimus vir Nicolaus Witfen, Amfteladamenfis Conful, atque Indice Orientalis Societatis Prefectus, poftquam Sape literis monuerat Primum Societatis Indica Prafectum Van Hoorn ut Semina recentia Caffé Mofcbâ Arabie Felicis urbe deferenda curaret, atque in infula Fava in cujus Metropoli Batavia babitabat, terre commilfa foveret; cui ille juffo parens, arbore fque inde nactus plurimas, unam mifit ampliffimo viro, qui ftatim quam liberaliffimè incomparabili boc Crnamento donavit bortum Amfleladamenfem, cujus 


\section{( 18$)$}

olim \& Conditor fuerat. Ibi tulit dein fructus, ex quibus fatis nove affiduo ftirpes prodeunt. Ita quidem, ut rariffme Arboris Spectaculum in Europa unius Wit fen cure debeatur \& liberalitati, errentque qui aliter bac de re publicè commentati funt, ut fuis ad me datis literis ipfe ampliffimus vir memonuit. The Authors M. Boerbaave here means, are probably the Relaters of that Story of the Dutch having ftollen away a whole Plant from Arabia; which we have already taken Notice of.

Concerning this Coffee Plantation in Fara, Monf. La Roque fpeaks in thefe Words: " The wife and fagacious Dutch have plant' ed Coffee brought from Arabia, near Batavia, and by tranf'planting, and other proper Methods, they have rais'd many - Trees there: The Succels, neverthelefs, does not fully anfwer, ' fince they continue ftill to fend Ships and ready Money into - the Red Sea to purchafe Coffee from the Arabians. It is pre' tended, that the too great Heat of that Climate is the Reafon " why the Fruit feldom comes to due Perfection. And indeed - Coffee Trees require a moderate Heat, much Shade, and a frefh ' free Air.' This Author acquaints us further, That the Englifs likewife had begun to plant Coffee at Fort St. George, in the Eaft Indies; but with fo little Succefs, that he was inform'd they had now laid afide all Thoughts of that Defign.

Whatever might be the State of the Dutch Coffee Plantations in fava, when M. La Roque wrote, they are now in a very thriving Condition; great Quantities of Coffee being every Year brought from thence into Europe. As for any Delign of planting Coffee about St. George, I never could hear that that was carry'd further than mecr Curiofity.

But now to return to the Amfterdam Garden, the Univerfal Nurfery of Coffee Trees for all the Weftern Parts of Europe; I can neither find in what Year that Plant was brought thither, nor to what Place the firft Trees were fent from thence. We may however probably conjecture, that the neighbouring Gardens of the United Provinces were firft fupply'd; but I find no printed Account of any fent out of Holland, before thole which Chriftoph. Volkamerus faw in M. Munnukhaufen's Garden in Germany; of which, as likewife of fome Seeds fent by Commelinus, the famous Botanick Profeffor at Amfterdam, to his Brother Foh. Georg. Volkamerus, he has given the following Account: Mifit Café fructus cera obductos conjunctiffimo fratri Dn. D. Foh. Georg. Volkamero, ex AmAerodamenfi borto Excell. Comelinn. Flore illud delicium. Arboris autem Café ferentis ramum quem bic delineavimus fumma liberalitas Excellentiffmi Domini L. B. a Munnickbaufen Magnce nunc Britan- 


\section{( I9)}

nic Monarche Potentifin, \& Electoris Brunfwicenfs Hannoverani (quem Deus T. O. M. Servet \& tueatur) The faurarius \& confiliarius intimus, ex borto fuo Swebberbano prope Hamelenfe Fortalitium extructo, cum regiis certe comparando, mibi quod grata mente recolo exhibuit.

This Account is dated in 17 I 4; M. Munnickbaufen mult therefore have had his Plant before that time; but we are fure it was in that Year (Mr. Bradley fays about the latter End of it) that the Magiftrates of Amfterdam fent a large Tree bearing Fruit in a Prefent to the late French King. Monf. La Roque faw it immediately after it was plac'd in the Royal Garden at Paris; and from what he fays, we likewife learn that there were fome fmall Plants there before. "On the $29^{\text {th }}$ of $\mathcal{F} u l y$, fays that Author, Monf. - De Fufleu, Doctor of Phyfick, and Royal Profeffor of Botany, ' was fo kind as to carry M. Galand, Arabick Profeffor in the - Royal College; M. Parent, of the Academy of Sciences, ' M. Onange, a learned Chinefe, and my felf, to the Royal Gar- den, to fee the young Coffee Plants that are there; but at our

- Arrival we were told that the King's firft Phyfician had fent

s thither the great Coffee Tree lately come from Holland, and

' which had been prefented to His Majefty by the Magiltrates of

- Amfterdam. We went therefore firt to fee this rare Plant; and

- we confidered it a great while with Pleafure. It was in a Cafe

' in the fame Glafs Frame with the Torch Thiftle of Perou, be-

' ing about five Foot high, and not above one Inch Diameter.

' It fhoots out divers little Branches that arife all along the Stalk,

' and altogether form almoft a Pyramid; the Leaves are all rank'd

' in Pairs, but not fo big as thofe I had from Arabia. And

- M. Galand perceiv'd no Difference between this Tree and one

- he had feen at Conftantinople. There was green Fruit upon it

- about the Size of a fmall Plumb; red Fruit almolt like a Cherry,

- and fome nearly ripe, of a much decper Colour. The Hol-

- lander who was intrufted with the Care of it, and came along

" with it from Marly, told us there was another ftill at Amfter.

' dam, much larger than this, being as high as the fecond Story

' of an Houfe, and proportionably thick. This great Tree came

- originally from Arabia, being tranfplanted very young, and

' carried to Fava, where after it had grown for fome time, it

' was at length fent to Amfterdam, and there continues ftill to

'profper. (In all this our Autbor was mifinform'd.) From the

- Fruit thereof a great many Trees have been rais'd; fome of

' which have bore Fruit at three Years old; and, as the Dutcbman

" cold us, the Tree fent to the King was of this Number. 


\section{( 20$)$}

' M. De fuffeu carry'd us afterwards to fee the other Plant which - came fome time before from Holland. It is as yet but very in- confiderable, bears no Fruit, and is but about a Foot and an ' half high, tho' very frefh and in good Plisht. But to return ' to the firt, in order to fatisfy my Curiofity compleatly, I want- ed now only to fee it in Flower; and this I had the Pleafurc ' of, by M. De 'fufreu's Means, in about five Weeks after. I faw - fome of the Flowers unblown, others perfectly open and fpread, - and from thence I was fully convinced of the Truth of every c thing I have advanced in my Memoirs on that Subject.

In this fame Year, 1714, Mr. Bradley tells us, the Dutcb fent over feveral Trees to their Settlement at Surinam in the Weft Indies, in order to cultivate them in that Country, where he thinks they will undoubtedly turn to good Account; as he is perfuaded they would do, if they were propagated in the South Parts of Carolina. That Trial I believe has not as yet been made, but there is now a very large Stock of Coffee Trees in Barbadoes; from whence not only whole Plants, but even fome Pounds of dry'd Fruit have been fent to England. And I am inform'd by Mr. Pbilip Miller of Chelfey, that in the Year 1720 , one Capt. Young carry'd the firit Plants from Surinam to that Inand. If we may believe Mr. Bradley, in his late Appendix, it is owing to His former Writings that ever they thought of cultivating Coffee there. 'I am, fays he, the more particular (about making hot-beds, - no noubt very neceffary in Barbadoes) on this account, becaure I ' now find that my former Writings concerning Coffee, have - brought that Plant to be familiar in our American Plantations, ' I mean the Ifland of Barbadoes, where at prefent there is a great - Number of Plants in a fruit-bearing State, from whence fome - have been brought to the Royal Palace at Hampton Court, in a 'profperous Condition; and I doubt not but the Plant, for its - Beauty and Curiolity, will be as much coveted by all Lovers " of Gardens, with us; efpecially fince the fame Expence, in " point of Culture, will ferve for the Education of all the choice - Fruits of the hottent Climates.

But to return to the Progrefs of the Coffee Plant in Europe. Being by this time pretty common in the Northern Countries thereof, it at length found its Way over the Alps into the Phyfick Garden at Pifa, from whence, no doubt, it has now fpread to the other curious Repolitories in Italy. It is M. Tilli, Botanick Profeffor at Pifa, who acquaints us with this Circumftance. The Grand Duke, he fays, being inform'd that the Coffee Tree was cultivated in the Amfterdam Garden, defir'd of the Director there- 


\section{(2I)}

of that he might have a Plant for his Phylick Garden at Pifa; and as they readily confented, it accordingly arriv'd fafe at $\mathbf{L e g}$ horn in 1715 , in the hotteft time of the Year, having fultain'd no Damage in the Voyage; and being from thence tranfported to Pifa, it continues there to flourifh and bear Fruit to Perfection, from which many young Plants have been rais'd. Hujus rariffime Plantic in Ampliffimo Amfteledamenfi horto Vegetantis ad Aures Regice Celfitudinis Magni Ducis Rumor pervenerat, \& ficuti omnes ejus impetus tam in genere Scientiarum quam in genere novitatis ad laudem femper funt propenfi, ut bonefta \& utilia qualibet animus ejus continue cogitet, banc plantam quoque ex borto Amfteledamenfi in Pifanam urbem transferendam cogitavit; binc factum ut tanti Principis nomine, claritate ac benervolentia illuftrifimi \& nobiliffimi ejus borti curatores ad nos Anno i 7 Is, hanc Café plantam titulo \&o defcriptione Fafmini Arabici Caftanee foliis flore albo odoratifimo a Doctiffimo Commelino facta, omni cura \& diligentia miferunt. Hinc \& Navis Gubernator fuam adbibuit operam \& follicitudinem; opportune enim Liburnum appulit; tunc aftus erat graviffimus, flagrantiffimo fidere Colum incaluerat, attamen a tanta Locorum diffintia, abfque ullo Hybernaculo nibil deirimenti acceperat.

When the Coffee Tree was firft feen in England, I am nor able pofitively to determine. Mr. Wise, His Majelty's chief Gardidiner, affures me, that fome time before the Death of the late Queen Mary this Plant was in the Royal Garden at Hampton Court; and I have been told, that the late Bifhop of London, Dr. Compton, had one at Fulbam in 1696 . brought directly from Batavia, by one Capt. Adams.

In the Year 1706 , Her Grace the Dutchefs of Beaufort (as I am inform'd by the Gardiner) had one at Chelfey.

In 17 I 2 it was certainly in the Right Honourable the Lord Vifcount Weymoutb's Garden at Long Leate in Wilthire. This appears by a Catalogue of all the Stove and Greenhoufe Plants and Annuals in that Garden, taken $\mathcal{F u l l}^{2}$ 28, 1714 , when that Nobleman died, communicated to me by my worthy Friend the. Reverend and Learned Mr. Harbein; in which Catalogue I find the true Coffee Plant tbree Foot high fent to my Lord from Holland, in 1712.

But the firft printed Account we have of any Plants fent from Amfterdam to England is by Mr. Bradley, in his firlt Treatife of Coffee, publifh'd in 1714 ; that is, in the fame Year in which he himfelf faw them in Holland. 'The Heer Gerebrand Pancrafs, - Commiffary of the Garden, and Prefident of the City of Am" Aerdam, did me the Honour to accommodate me with this great 


\section{( 22$)$}

c Curiofity, which I fent into England, and intrufted to the Care - of Mr. Thomeas Fairchild, a moft accurate Gardiner at Hoxton.

Dr. Sherrard has been fo kind as to inform me, that about the Year 17 I 9 he fent a Coffee Plant to Dr. Eudal at Enfield; and in 1723 , his Brother, Mr. Sherrard, had fome for his fine Garden at Eltham, likewife directly from Holland.

In 1724, Mr. Parker of Heling had two Plants fent him from Amferdam.

There has been likewife a good Number of Plants fent direct. ly hither from Barbadoes. Thofe that came laft Summer to His Majefty, were fent by the Governour of that Ifland, and entrufted to the Care of Dr. Gamble. His Royal Highnefs the Prince, and the Duke of Chandos had fome by the fame Ship.

\section{H A P. IV. The Coffee Plant in general.}

I $\mathrm{N}$ this Chapter my Defign is only to lay before the Reader a fhort View of the Sentiments of Authors concerning the Genuis of this Plant, with refpect to Theophraftus's general Divifion of Vegetables; and to remark the other Plants to which it has been compared. The Obfervations which belong to this Place, are therefore fuch only as could not conveniently be rank'd under any Head of the following Defcription, and at the fame time ferve to convey a general Idea of the whole Plant, the particular Parts of which I am afterwards to examine.

Every Body knows that Theopbraftus has divided all Plants into thefe four Claffes, Trees, Shrubs, Under-fhrubs and Herbs. The Coffee Plant has been thought by different Authors to belong to every one of thefe; for it is by fome called a Tree, by others a Shrub and Bufh, by others an Herb, in exprels Terms; and by others, in fine, it has been compared to different Plants of all thefe Kinds.

Alpinus, the firft Author who has mention'd the Coffee Plant, calls it a Tree, and compares it to the Euonymus, a few things excepted concerning the Figure and Subftance of the Leaves. It is not eafy to determine what Euonymus is here meant; did he not feem to place the chief Difference between the Coffee Plant and that, in the Leaves, I fhould be apt to think he had in view 


\section{( 23 )}

the Spindle Tree, which grows commonly in Hedges in mort Counties of England, for the Leaves thereof bear a very great Refemblance to thofe expreffed in Alpinus's Figure.

F. B. who only copies from Alpinus, what he has faid about this Plant, agrees with him likewile in calling it a Tree, and both he and his Brother C. B. compare it to the Euonymus, without any farther Explication.

Petrus de la Valle, the celebrated Italian Traveller, in a Letter dated at Conftantinople, 1615 , calls it alfo a Tree. It grows, he fays, near Mecca; and of the Fruit the Twrks Drink is made.

Garcias Silva Figucroa, in the Account he has given us of his own Embaffy from Spain to Perfia, begun in $16_{1} 7$, tells us that the Perfians made their Coffee of certain Herbs.

Veflingius, in his Notes on Alpinus, 1638 , gives this Plant the Name of a Tree; but at the fame time owns he had never feen it.

Parkinfon compares it to the Prickle Timber, or Prickwood Tree, which he takes to be the Euonymus of Alpinus.

Banefius, in the firt Treatife that was ever publifi'd expreflly on Coffee, $167 \mathrm{I}$, is likewife the firft whom I find to have called this Plant a Shrub or Bufh; which are the Names he conftantly gives it thro' his whole Book. And as he has likewife quoted Alpinus's Account of it, 'the EnglifbiTranllator thinks fit to add, by way of Note, that the Euonymus is by our Botanifts term'd the Spindle Tree, or Prickwood; but it is believ'd (fays he, without telling us by whom, or for what Reafon) that it is not Alpinus's Euonymus.

Chabreus, in his Seiograpbia Stirpium, 1678 , joins with the other Authors in calling the Coffee Plant a Tree; but it is meerly upon the Authority of Alpinus, who indeed is the only Perfon, during all this time, that appears to have ever feen it; for Banefuns no where fays that he did; and the reft either frankly own they never did, or fay nothing about the Plant.at all.

Monf. Bernier has fomething new upon this Head, but we fhall fee prefently, from Monf. La Roque, that he has been very ill inform'd. 'I cannot tell you (fays he to Monf. Du Four, in a Leter publifh'd with that Author's Treatife on Coffee) ' whether - Coffee be a kind of Bean, which is fown every Year as we do ' ours, or the Fruit of fome Shrub; I find nothing upon that " Head in my Journals; but what I can affure you of is, that - it mult be a Species of Convolvulus, becaufe I remember perfectly well to have been told that it is always planted near the 'Mouzé, to which it clings, and fo fupports its felf.' This 


\section{( 24 )}

Souzé is what the Portugueze call Adam's Fig Tree, becaufe of the Largenefs of its Leaves.

It is no Wonder that this Account ftartled Dr. Robinfon, and that, having nothing but Alpinus and his own Obfervations on the dry'd Coffee Fruit to be guided by, he was at a Lols what to make of it. ' M. Bernier, who pals d the Red Sea into Arabiu, (fays the Doctor to Mr. Ray, in a Letter publifh'd not long ago by Mr. Derham) ' doth affirm, That the Arabs affured him that ' the Coffee Fruit was fown every Year, under Trees, upon which

' it did climb and run. From which he concludes it to be a ' Species of Conroloulus. I think he might as well have con- cluded it to be a Phafeolus, or fome other fcandent Legume-

- If M. Bernier was truly inform'd of its annual fowing and climb- ing, then Alpinus never faw the true Coffee Plant_- I have ex' amin'd many Coffee Berries, as they call them, here in London, ' and am almoft perfuaded by my own Obfervation that they are ' neither Berries nor the Seeds of any Convolvulats, nor of any

"Legume, but are rather of the Nut Kind.

Du Four's Treatife of Coffee was printed in 1683 , and in the Beginning thereof he terms the Coffee a Legume, or kind of foreign Bean; but when he talks of the Plant it felf, he is not altogether againft its being called a Tree, tho' he inclines more to rank it among the Shrubs. "The Tree that produces the Coffee (fays he) ' is like the Euonymus or Spindlc Tree (Fufain in French) ' which bears the Seed we call Bonnet de Pretre, as we are inform'd - by Alpinus, who faw it in his Traveis. In the Memoirs which - I have received from the Levant, it is compared to our middling - Sort of Cherry Trees, both in Leaves, Branches and Size, for ' at moft it is but a Shrub.

Blegny compares the Trunk of the Coffee Plant to a common Bean Stalk. What led him into this Miftake was his looking on the Branch delineated by Alpinus, to be the whole Plant.

As Du Four's Book was the lateft, and, as Mr. Ray owns, the beft that he had heard of about Coffec, when the fecond Tome of his Hiftory of Plants came out, we need not be furpriz'd to find that he imitates him in calling it a Shrub.

In this, and in nothing elfe, he is followed by the Worthy and Learned Sir Hans Sloan, whofe Account of this Plant, pub. lifh'i in the Pbilof. Tranfact. $N^{\circ} 208$, is by far the molt exact that had till then appear'd.

Mr. Dale, in his Pharmacologia, 1710 , ventures to diffent from Mr. Ray in this Particular, and calls the Coffee Plant a Tree. This was certainly not the Effect of any Knowledge he had of the 


\section{$(25)$}

Plant, for in the very next Line he tells us it is Arbor fregrondis, a Tree of an extraordinary Size; and compares it to the rilia, or Lime Tree.

Dr. Salmon agrees with Dale in calling the Coffee Plant a Tree; but inftead of the pregrandis of that Author, he fays it is but a very little Tree.

Sir Thomas Pope Blount, in his Natural Hiftory, 1693 , takes Notice (from Du Four I fuppofe) of the Refemblance of it to the Cherry Tree, except that it is farce fo big.

Dr. Pechey, in his Compleat Herbal, 1694, calls it a little Tree; but rather than to fay he copy'd Dr. Salmon, I fhall fuppofe he tranflated the Arbufculum of Mr. Ray.

Pomet, after finding Fault with Blegny, tho' without naming him, tells us, (Hiftoire des Drogues, 1694, ) that for his Part, he rather inclines to $\mathcal{F}$. Baubinus's Opinion, that it is like the Spindle Tree. How can this Author have ever read $\mathcal{F}$. B. and not fee that he copies Alpinus?

Herman acquaints us, in his Pofthumous Treatife of the Materia Medica, publifh'd 17 1 0 , that the Coffee Trees grow in Arabia Felix, and that they are as big as Lime Trees. As this Book was handed about in Manufcript long before it was printed, it was from thence, perhaps, that Dale got this_Comparifon.

The two Lemerys ftick by $\mathcal{F} . B$. and only refer to him for a farther Account of this Plant.

It is hard to tell upon what Langius founded the Refemblance, when, in his Materia Medica, 1 704, he compared the Coffee Plant to the Filix; or how, after fuch a Comparifon, he fhould ftill call it a Tree.

Tournefort has no where mention'd this Plant, but in a Porthumous Treatife of the Materia Mediua; and even there he has only copy'd Du Four.

Chomel, in his Plantes Ufuelles, $17 \times 2$, and Andry, in his Alimens $d u$ Carême, 1713 , call it fimply a Tree which grows in Arabia Felix.

Valentini, in the Latin Edition of his Materia Medica, publifh'd in 1716 , tells us it is an exotick Tree as big as the Lime Tree.

C. Commelinus is the firft who has been at Pains to examine this Plant with a View to difcover the Family it belongs to; for neither Morifon nor Tournefort in his Inftitutions, have fo much as mention'd it; and the Way that Mr. Ray has clals'd it is only by Guefs. According to this Author, the Coffee Plant is a Species of Jeflamin; and Volkamerus, in the Acad. Cafar. Leopold. Ephein. obf. x 68. adds, that it is of the Bacciferous Kind. 


\section{( 26$)$}

Meffieurs La Roque and De Fufieu have given us fo exact and compleat a Defcription of this Plant, that they had no Occafion to compare it to any other, as a Mean to convey a better Idea of it; and after what they have faid there can no more Difficulty remain whether it ought to be ranked among the Trees or Shrubs. La Roque adds, en paffant, that when at its full Growth it is not unlike an Apple Tree. But what we have principally to remark. from this Author's Account, is an Obfervation which lets us into the Reafon of M. Bernier's Miltake, and clears up the Difficulty which Dr. Robinfon was in about it. 'If our Travellers, fays Monf. La Roque, ' had not made this Journey to Mouab (the ' City where the King of Yemen then refided) we fhould perhaps ' have long remain'd ignorant of one Singularity about the - Coffee Trees, of which no Body has hitherto taken Norice; ' and that is, that in Places very much expofed to the South, ' or which lie too open, thefe Plants are fet under great Trees, ' which they fay appear'd like a kind of Poplars, and they ferve ' to fhade and defend the others from the exceffive Heat of the

- Sun. The Inhabitants are perfuaded that without this Canopy

' the Flowers would foon be burnt up, and no Fruit ever appear;

' and our Travei'ers faw fome Intances of this in other Trees

' which had not the Advantage of a Shade. They obferv'd this

' in the firft Coffee Trees they met with in their Journey: It was

' in a Plain near the City of Tagus, which is very much expos'd.

- The Poplars ftood at certain Diftances all over the Plantation,

' and each of them thaded a good Number of Coffee Trees re-

- gularly planted for that Purpofe, much after the Manner that

- Apple Trees are in Normandy. In other Places which do not

- lie fo open there are none of thefe Trees to be feen, the Coffee

- Plants thriving well enough there wihhout a Shade.

Thus far Monf. La Roque. And thefe were undoubtedly the great Trees which Bernier had been told of; for which he could imagine no other Ufe than that they fupported the Coffee Plants, as others do the Convolvuli.

Profeffor Boerhaave agrees in every thing with Commelinus. It was fufficient for the Defign of his Index, publifi'd in 1720 , to name and clafs this Plant as he had found it done, by any good Author before him.

According to Mr. Foseph Miller, in his late Botanicum Officinale, the Coffee Plant feems to be neither Tree nor Shrub, but fomething between both; which he expreffes by calling it a frubby Tree. He is likewife afraid to make it a Species of Fafmin, but fays only, that it is fo according to Commelinus.

Mr. 


\section{( 27 )}

Mr. Bradley is as pofitive on the other hand, that Commelinus was in the right; aud affures us that every Day confirms him more and more that it is of that Tribe.

In this Manner have Botanical Writers talk'd concerning the Coffee Plant in general; and if we look back on all that has here been quoted from them, we fhall find,

1. That of all the Authors who have faid any thing upon this Subject, the greateft Part are agreed that this Plant is truly and properly a Tree, and ought to be reckon'd fuch.

2. That of the remaining Authors, Banefurs, Mr. Ray, and Sir Hans Sloane, think it is properly a Shrub; Du Four, that it may be reckon'd either a Tree or Shrub; Miller, that it is neither the one nor the other, but a fhrubby Trec; Figueroa, that it is an Herb; Langius, that it is both Herb and Tree; and Bernier is altogether undetermin'd about it.

3. The other Plants it has been compar'd to, and the Authors of thefe Comparifons, are the following,

Euonymus,

Alpin.

Prickle Timber Tree,

Parkinf.

Convolvulus,

Bernier.

Cherry Tree,

Du Four.

Common Bean,

Blegny.

Tilia, or Lime Tree,

Dale.

Filix, or Fearn,

Lang.

Jeffamin,

Commelin.

Apple Tree,

La Roque.

C H A P. 


\section{$(28)$ \\ C H A P. V. \\ The Root, Trunk and Branches of the Coffee Plant.}

7 HO' the Coffee Tree is now to be found in many Gardens about London, it has been my. Misfortune as yet never to have had a full Opportunity of examining thefe Parts of it which make the Subject of this Article. I hall, however, venture to communicate the few Obfervations I have hitherto been able to make about them; leaving a more perfect Defcription of them to be fupply'd by fome other Hand, in cafe I hould never be in a Condition to do it my felf.

The Coffee Fruit being planted in a convenient Soil, the firft Part of the fucceeding Tree which appears above Ground, is the feminal Leaves; and as foon as they are fpread, the tender Stem may be perceived to fprout out betwixt them tip'd with two other Leaves of the fame Kind with thofe that always remain on the Plant. From between thefe, another Portion of the Stalk may in a little time afterwards be perceived to thoot, crown'd likewife with a new Pair of Leaves lying in a Plain which cuts the former at right Angles; and in this manner the tender Trunk ad. vances.

How long it is before the firft Branches begin to appear, I cannot certainly tell; I faw a young Plant in Mr. Sherrard's Garden, feven Inches high, bearing five Pair of Leaves, befides the feminal ones, without any Veftige of Branches. But when they do arife, their Manner of Growth is much the fame with that of the Truik. They come out in crofs Pairs from the Ale of the above-mention'd Leaves, and all of them make acute Angles with the Stem, thofe neareft the Top being molt inclined.

Neither is the Defcent of the Root, in all Appearance, much different from the Afcent of the Trunk and Branches; for in a very fmall Plant which I had the good Fortune to get with the Root entire, I obferv'd it to run down for a good way pretty ftrait, and that afterwards it bent feveral Ways, very long Fibres arifing from it thro' its whole Length, moit of them ftanding the fame Way as the Branches do on the Trunk, only much more numerous, and, as far as I could find, in a Pofition not always exactly regular. As the Plant grows up, fome of the Fibres 


\section{(29)}

which lie neareft the Surface of the Earth become equal to the main Body of the Root in Thicknefs, and fend out other fmall, ones in the fame Plenty; and in this Manner it fpreads to a confiderable Breadth as well as Depth, thefe feveral Digiti fhooting out different Ways, and at different Angles with the Horizon. This is all that I could with Certainty difcover in another pretty large Root fent me by a Friend; but which by Misfortune had been cut and mangled when dug up.

To what Height and Thicknefs thefe Plants will grow with us, cannot as yet be determin'd, there being none, as far as I know, in England which have reach'd their utmoft Limits of Increafe. Mr. Parker of Heling has one which laft Summer was full five Feet above Ground; the Circumference, near the Root, was three Inches, and from thence it rifes gently tapering, the Top being no thicker than a mall Branch. At the going off of each Branch there is a confiderable Nodus, efpecially near the Top, but the Joints below each of them are always bigger than thofe above them. In this Plant I counted eighteen Pair of Branches; the longert, which was in the third or fourth Row from the Ground, meafuring eighteen Inches in I.ength, and three quarters of an Inch in Circumference.

The Cortex or Bark of this Plant is pretty thick, and may be plainly difcern'd to be made up of two Parts, cafed over one another; the outermoft of which feems to me to fall off from the Trunk and greater Branches, which makes thefe appear of a lighter Afl Colour than the reft; the upper Covering of the Bark being feveral Degrees darker than the other.

The Wood is pliant and flexible, of a much whiter Colour than any Part of the Bark, and fpecifically lighter than molt other Trees. This becomes the more remarkable, becaufe the Pith is but of a very moderate Size.

What has here been faid about the Cortex and Wood of this Plant, agrees equally to the Root and Trunk, at leaft as far as I have hitherto been able to obferve.

I thall conclude this Account with the following Obfervations communicated to me by that ingenious Gardiner Mr. Pbilip Miller, concerning the Coffee Trees which were lately fent from Barbadoes to His Royal Highnefs the Prince. The Height of them from the Surface of the Ground was, in September lait, fifty two Inches. Each Tree hath thirty two Branches, which come out by Pairs, oppofite to each other. The lowermolt Branches were twenty five Inches long; and fo decreafing in Length to the uppermoft, which was three Inches long; and all together they form a handfome Pvramid. 


\section{( 30$)$}

The Stem of the Tree next the Surface is three Inches in Girt, and at the Top an Inch and three quarters.

The Root fpreads nineteen Inches Diameter, and is very full of fmall Roots. The larger Roots were of a dark brown Colour; but the Fibrille very white, and pretty tough; and when broken they fmell very like Liquorice, but have little or no Tafte. The whole Root is fo ramify'd, and each Ramification fo full of Fibrille, that it looks like a fhockey Head of Hair; and it was very difficult to clear them of the Earth.

In no Author, that I have yet met with, is there fo much as one Word about the Root of the Coffee Plant. Pomel indeed tells us of one that was eaten by the Rats, near Paris; but befides that this Story is in all Probability falfe, we are as far to feek about the Defcription of this Root as ever.

Of all the Europeans who have travelled into Arabia Felix, where the young Coffee Plants are every where tranfplanted at certain times of the Year, it is a Wonder that none has ever had the Curiofity, either by ocular Infection, or at leaft from the Accounts of the Tnhahirante, to inform himfelf what kind of Roots they have. And it is a much greater Wonder ftill, that during a Courfe of fo many Years, in which there have been Plants fent to all Places, from the Amfterdam Garden, that no Botanift who has had an Opportunity of examining the Roots, has ever publinh'd a Defeription of them.

The Trunk and Branches, having a nearer Relation to the Fruit, and being difcowerable with much lefs Trouble than the Root, have not been fo much neglected by Authors.

Alpinus has faid nothing in particular about either of thefe; but fuppofing the Figure he has given us of a Branch to be in any meafure like the Plant it was taken from, we may infer from thence, that it decreafes very fenfibly in Bignefs, as it removes from the Trunk, till at Top it appears to be not much thicker than the Foot Stalks of the Leaves: That it is not quite ftrait, but gently bent two contrary Ways in form of an Italian $\int$; and that there are three leffer Branches arifing from it, the uppermoft about the Middle, and all of the fame Figure with it.

From this Time, all the Way down to Monf. Du Four, we meet with nothing but repeated Copies of Alpinus's Figure, without any Defcription; and even this Author has only told us that the Branches are fmall and limber ; referring for all the, other Particulars about them, as well as about the Trunk, to the Figure placed at the Beginning of his Book; which is only a good Copy of that of Alpinus.

Sir Hans Sloane's Figure is likewife taken from a Branch, and differs extremely from all that ever I have feen in the Number and Difpofition of the fmaller Twigs that arife from it.

About the Defcription of it, the Author tells us that it was taken from a Tree feven or eight Foot high; that the Branch it felf was five Foot long, and cover'd with a grey. almoft fmooth Bark. The Wood is white, and the Pith not very large. The Twigs are cover'd with a darker colour'd very. fmooth Bark, and arife oppofite to one an:other by Pairs, ftanding crofs to one another, coming out of oppofite Sides of the Branch, or the two Pairs next to one ano= ther, cutting each other at right Angles.

The Branch from whence this Defcription is taken, was dried; but neverthelefs, he fays, it will every way agree to thofe of a growing Tree; Mr.Clyves, who broughe it to Exgland, having inform'd him of every Particular of it.

Monf. De Funfien tells us, that in the Year.1715, the Coffee Tree in the Royal Garden at $P$ aris was about five foot long, and the Trunk as thick as a Man's Thumb. The Branches arife at certain Diftances, always in Pairs crofling one another: They are very limber, round, knotted and cover'd, as well as the.Trunk, with a very thin white Bark. The Wood of them is pretty hard, and of a fweet Tafte. The lower Branches are commonly fimple, and arife more horizontally than the upper ones, in . which the Trunk ends, and which are fubdivided into leffer Twigs fpringing from the Ala of the Leaves in the fame Order.

Valentini refers to the Count Marfigli for an Account of this Tree, and has only copy'd one of the Figures of that Author.

Monf. $L_{a}$ Roque, from Informations taken in Arabia Felix, informs us that the Tree which bears Coffee is from fix to twelve Feet in Height, and from ten to fifteen 


\section{( $\left.3^{I}\right)$}

Inches in Circumference.. When in Perfection it looks not unlike an Apple Tree eight or ten Years old. In an aged Tree the lower Branches are ordinarily bent; and at the fame time they fpread themfelves all round the Trunk, and fo form a Sort of Umbrella. The Wood is very tender, and withal fo pliable, that the Extremities even of the higheft Branches may be brought within a Foot or two of the Ground without breaking. The Bark is of a whitifh grey Colour, and the Surface of it fomewhat uneven.

Concerning two other Trees which this Author $\mathrm{f}_{2} \mathrm{w}$ in the Royal Garden at Paris, he obferves that one of them was only about a Foot and an half high; the other, then juft arriv'd from Holland, was about five Feet in Length, and an Inch in Diameter. Little Branches arofe all along the Stem, and taken all together they form'd almoft the Figure of a Pyramid.

Mr. Bradley has been at Pains to examine and delineate the Coffee Trees that grew in the Amfterdam Garden. His Figure, however, is only that of a Branch, which he tells us refembles in every Point that he took it from, except only the Size, which oughe to be one third bigger to make it equal with the Life. About the Trunk or Branches of this Tree he has faid nothing, further than that it is of a very quick Growth, and naturally inclinable to thoot upwards; that in its native Country it generally attains, as is reported, the Height of forty or fifty Feet, altho' the Stem, in the thickeft Part, does not exceed five Inches in Diameter. Hé adds, That in the Garden of Amfterdam there were two Coffee Trees about feventeen Foot high when he faw them.

As this exceffive Height afcribed to the Coffee Trees by Mr. Bradley, is only upon the Teftimony of other People, it ought to be of no Force againft the Truth of the Memoirs furnifh'd to Monf. $L_{a}$ Roque upon that Subject; and I am even afraid Mr. Bradley did not accurately mea. fure thofe he faw at Amfterdam.

\section{H A P. VI. \\ The Leaves of the Coffee Plant.}

7 HE Leaves of the Coffee Plant terminate both Ways in a narrow Point, and from thence are expanded on both Sides in the Figure of a Curve Line, fo as that the broadeft Part of them is commonly about the Middle of their Length. Their regular Figure is to have this Curve Line fimilar, an equal Part of the Leaf lying on both Sides the Cofta or Rib. They are not all, however, of this Shape, and the Variations from it confift either in that the fame Parts of the Leaf are not equally broad on each Side of the Cofta; or that the Extremities of them are laterally bent or incurvated; both thefe admitting of many different Degrees.

The Length of the largeft Leaf which I had ever an Opportunity of meafuring was nearly feven Inches; the greatelt Breadth two Inches and three quarters. The whole Circumference can feldom be exactly mealured in a large Leaf, becaufe the Edges are moft commonly undulated; but as near as I can guefs from the Largenefs of the Undulations of the Leaf I have now before 


\section{$\left(3^{2}\right)$}

me, the Circumference of it is between feventeen and eighteen Inches.

Thro' the Middle of each Leaf lengthwife runs a ftrong Cofta or Rib, rifing above the Surface on both Sides, but molt on the lower or back Side. It decreafes in Thicknefs as it advances towards the Extremity, being thickeft near the Branch to which it is fixed; and as during a fmall Space from thence the Leaf is extremely narrow on both Sides, that Part has been taken for a Pedunculus or Foot Stalk; and in the Leaf I have here given the Dimenfions of, it is about half an Inch in Length.

From each Side of the Colta arife a great many Fibres of different Sizes, the largeft being parallel to one another, and inclined obliquely towards the End of the Leaf. The others are fpread irregularly thro' the Pulp of the Leaf, which is pretty hard and folid, tho' not very thick.

The Surface and Edges of young Leaves are fmooth and even, except where Rifings are form'd by the Colta and large Fibres; but as they increafe, the Edges become commonly pinched, the reft of the Leaf undulated or wav'd in many different Manners, bending likewile fometimes both according to the Length and according to the Breadth.

The Leaves while frefh are all pretty much of the fame Colour, the upper Side being of a deep graffy green, the under Side lighter by a good many Degrees.

Hitherto we have confider d the Leaves by themfelves; the next Step is to cxamine them on the Plant. From the time that the Trunk appears above Ground, till the Branches are thot out, Leaves grow upon it in the fame Order as the Branches do afterwards. In a young Plant only feven Inches high, I counted five Pair, befides the feminal ones, and the largent of them was four Inches in Length. Thefe feminal Leaves differ from the reft in Shape, being more nearly circular, and adhering to the Stem by the Sides, rather than by one End. Some Leaves are found on the Trunk, even after the Branches are out, in all Ages of the Tree, and they grow always clofe by the Root of a Branch, but without being pair'd as before.

Two very tender Leaves are always found at the Top of the Trunk, join'd to a fmall thort Foot Stalk, arifing from between the Pair immediately below them. This Foot Stalk increafes and becomes a new Joint or Internodium of the Trunk; but before it has gain'd any confiderable Length or Strength, a new one tip'd with other two Leaves thoots out. from its Top, betwixt the two Leaves placed there. In this manner the Tree increafes in 


\section{( 33 )}

Height; and the Growth of the Branches is perform'd in the fame manner.

On thefe all the other Leaves are to be found. They arife from the Nodi already mention'd in an oppofite Situation to one another; that is, one on each Side; but they are all in the fame Plain, in which they differ from thofe of the Trunk; and in their natural Situation, before they come to be bent and diftorted, both Edges are at an equal Diftance from the Horizon. The Number of Leaves on each Branch, is, I believe, pretty nearly proportionable to the Length of the Branches. On one, which meafured eighteen Inches, there were fixteen Pair of Leaves, but the Diftance between each Pair is not always the fame.

The Size of the Leaves on the fame Branch is ftill more different; neither are the largeft always neareft the Trunk, but indifferently on any other Part of the Branch; and it is certain that all of them do not arrive at the fame Dimenfions before they decay. The firf Sign of that is a Change of the Colour from Green to a light Yellow towards the Top; from thence it fpreads over the whole Leaf, and to that a brownifh Colour fucceeds, but not till that Part of the Leaf where it is found is quite dry'd and wafted. The Time when this happens, with refpect to every fingle Leaf, is not long after it has grown to its full Extent; tho' I am apt to think that their being fo clofely pent up in Stoves may contribute fomerhing to the Shortnefs of their Duration; the Plant it felf, neverthelefs, is undoubtedly an Ever-green; and I believe there is very little Difference to be obferved in the Number of green Leaves in any Seafon of the Year; but whether, or in what time young ones grow out from the fame Nodus from whence the old ones fell, I have not had an Opportunity of obferving.

Alpinus has only obferv'd alsout the Lcaves of this Plant, that they are thicker, harder and grecner than thofe of the Enonymus, and that they remain always green (perpetuo virentia): This laft, as, we have heard, mutt be meant of the whole Plant, not of any fingle Leaf. In his Figure the Shape of the Leaves is very ill reprefented; but the Manner in which they arife from the Branches tolerably well, if we except the croffing.

Monf. Du Four obferves further, That they are not very large, but pretty thick, in proportion to their Extent; that they are intire, or without Incifures; and that in every refpect they are very much like thofe of a middling Cherry Tree. He takes Notice likewile that this Plant is an Ever- green, but however that the Leaves decay and fall off yery foon, the Fruit remaining naked and expos'd upon the Tree. This Defcription is meant of the Coffee Leaves in Arabia Felix, none of which Monf. $D_{\text {w }}$ Four ever faw, and therefore the Inaccuracy of it is to be imputed nor fo much to him as to thofe from whom he had his Informations.

Sir Hans Sloane is the firft who has exprefs'd the Manner in which thefe Leaves arife from the Branches; and he has likewife added feveral new Obfervations about them. ' After the fame manner, fays he, - ftand the Leaves on the Twigs, as the - Twigs on the Branches, at fome times an - Inch, fometimes two Inches Diftance, - each Pair of Leaves from the other. The $\mathrm{K}$ 


\section{(34)}

- Leaves have $\frac{x}{4}$ Inch Foot Stalks, being - about four Inches long, and two broad

- in the Middle where broadeft, whence

- they decreafe to both Extremes ending in

- a Point. They are fmooth, whole, with-

- out Incifures on their Edges, fomewhat

- like the Leaves of a Bay." When we confider that this Author had only the Leaves of one dry'd Branch to take this Defcription from, it muft be own'd that he has examin'd this Part of it with great Accuracy; and as for the Comparifon he makes of thefe Leaves to thofe of a Bay, it is at leaft as juft as any that have hitherto been pitch'd upon; efpecially while the Leaves are fmall and not curled.

Commelinus, and after him Volkamerus and others, compare thefe Leaves to thofe of the Caftanea or Chefnut Tree. It muft be own'd, that from a tranfient View of what the Gardiners call the Spani/ $b$ ChefnutLeaves, one would be apt to think that they refembled the large ones of our Plant very much; but upon a more ftrict Examination, I find them to differ extremely. The Chefnut Leaves are much narrower in proportion to their Length ; the large Fibres much thicker fet, arifing higher on the backfide of the Leaf, and much more diftinctly continued to the Edges; the Edges are pretty deeply crenated, and the Interftices between the Notches end in ftrong Tharp Prickles or Thorns; the Undulations are not near fo large, and quite otherwife difpofed; in fine, tho' this does not relate to the Make of the Leaf, thofe of the Chefnut do not arife in Pairs from the Branches, nor in the fame Plain with one another.

Tournefort has nothing new about the Coffee Leaves; "They arife, fays he, in - Pairs oppos'd to one another, being of - an oval Figure, but ending in a fmall - Point.

M. Bradley tells us that the Leaves are bicompofite, or fet in crofs Pairs at the Joints, and not unlike thole of the common Bay, but curled at the Edges, and inclinable to hang down. And in the fecond Edition he inclines rather with his learned Friend Mr.Pettiver, to think the Leaves like thofe of the Laurus Vulgaria, that to compare it to thofe of our common Chefnut; but in all the Editions of his new Improvements, even thofe publin'd fince his laft Treatife of Coffee, he inclines to the common Chefnut again.

I need not take notice of the Defectivenefs of what Mr. Bradley has told us about this Part of the Plant; but I cannot help remarking his Miftake about the Situation of the Leaves upon the Branches: They are never fet in crofs Pairs, but lie all in the fame Plain; and on the Trunk, except before the Branches fprout out, they are feldom in Pairs at all. So that with refpect to neither of thefe will Mr. Bradley's Account of the Situation of the Leaves be found to hold.

Monf. De Fufferi's Defcription is in thefe Words: ' Both Sorts of Branches are - always cover'd with Leaves, intire and - without Incifures in their Circumference, - fmall and pointed at the two Ends, op' pos'd by Pairs, but without croffing one - another as the Branches do, and arifing - from the Nodi of thefe. They refemble - very much the Leaves of the common - Bay, but are not fo dry nor thick, tho" - larger and more pointed; their Extremi- ties inclining fometimes a little to one - Side. The upper Surface of them is of - a fhining Green, the lower Side of a c pale Green; and they are all yellowin at - firft. They are wav'd or curl'd at the - Borders, which perhaps is owing to the - Culture; and there is nothing aromatick - nor uncommon in their Tafte. The - biggeft of them is about three Inches in - Breadth, and four or five in Length, 6 with hort Foot Stalks join'd to them. Monf. La Rogue obferves, 'that thefe' - Leaves are very like thofe of the Limon - Tree, (Citronier) but not fo much point- ed; thinner, and of a darker green $\mathrm{Co}$ - lour. That the Branches are at no time - altogether Atrip'd of Leaves; that they c arife moft commonly in Pairs from the - two oppofite Sides of the Branches, and - all in the fame Plain, at fmall Diftances s from one arother. 


\section{$(35)$ \\ C H A P. VII. \\ The Flower of the Coffee Plant.}

7 HE Flower arifes from the very Middle of the Ale foliorum, or Juncture of the Leaves and Branches, by a fmall green Pedunculus, or Foot Stalk, which tho' not above the eighth Part of an Inch in Length, may neverthelefs be plainly perceiv'd not to run in the fame Plain with the Branches, but to be a little inclin'd upwards; and for that Reafon the reft of the Flower appears to be fituated not fo much between the Leaf and Branch as above them both.

Round the Edges of the upper Extremity of the Pedunculus, arifes the Calix or Cup of the Flower; and is prefently after divided into four or five fmall Segments; two of which, commonly larger than the reft, we may obferve to be of the fame Texture and Shape with the Leaves of the Plant, and to run up a little way upon the tubulous Part of the Petalum, at a little Diftance from it; for this Reafon, and alfo becaufe the Foot Stalk being fo very fhort, it is not always eafy to diftinguifh whether thefe Segments arife from it, or immediately from the Ala; they might equally be fuppos'd to be the Beginnings of new Leaves fpringing out with the Flower, only that they decay foon after it, leaving the Fruit naked. This evidently proves that they are all of the Nature of a Calix, the Ufe of which is to ferve firt for a Periantbium, before the Flower is quite blown, and afterwards to defend the tender Ovarium.

\section{O VARIUM.}

This Ovarium, or Seed Veffel, is fix'd to the upper Extremity of the Pedunculus within the Calix; and confider'd in this State, that is, as making a Part of the Flower, it is only a fmall green Globule, in which nothing farther can with Certainty be diftinguifh'd, till after the Decay of the Flower. Then it begins to fwell, and by degrees advances to a perfect Maturity, as we thall fee in defcribing the Coffee Fruit. 


\section{$\left(3^{6}\right)$}

\section{PETALUM.}

From the Top of the Seed Veffel fprings the Petalum of this Flower, by a tubulous Beginning, but it is afterwards parted moft commonly into five Segments, fometimes into four or three only. The lower or tubulated Part is exactly in the Shape of the Neck of a common Funnel, being narrower at Bottom than at Top; and the Length of it is between a quarter and three eighth Parts of an Inch. The Segments do not run up from it in a ftrait Line, but go off almolt at right Angles, and fo form rather a Difcus, than the upper Part of an Infundibulum, in the Senfe affigned to thefe Terms by Tournefort. They are all pretty much of an equal Length in the fame Flower, being commonly about half an Inch. Neither do they differ any other ways in Figure, fave only that fome of them continue of an equal Breadth thro' their whole Length, others begin, a little way from their Extremity, to contract by degrees. The Colour of both Parts and both Sides of the Petalum is the fame, a very pure white; which however I have fometimes obferv'd to be brighter in the Segments than in the Tubulus.

\section{$S T A M I N A$.}

The Stamina arife from the Infide of the lower Part of the Petalum, always equal in Number to the Segments thereof, of a white Colour, and a very fmall Size. Before they reach' as high as the Origin of the Segments, they ceafe to adhere to the Tubulus, and run up a little way above it, being, as far as they are diftinctly vifible, never above three eighth Parts of an Inch in Length.

\section{$A P I C E S$.}

To each of the Stamina is join'd an Apex or Pendant, fomething longer than they are, and of a very different Figure. I know nothing they can be fo juftly compar'd to as the Claws of fome fmall Birds; for they are crooked or bent fulcated on the concave Side, and bigger at 'Bottom than at Top. 'In this Sulcus the Stamina are fix'd, a little above the lower Extremity; fo that thefe and the Apices have an oblique Situation, with refpect to one another. All the convex Side of the Apices is of a whitifh yellow Colour, the concave Side of a dark brown. 


\section{( 37$)$.}

\section{$S T \Upsilon L U S$}

The Stylus is a long frait fmall white Tube, fpringing from the Middle of the upper Side of the Orvarium within the Petalum, thro' the hollow Part of which it afcends in the very Center of the Stamina and Apices. In this manner it runs up for near an Inch, and then the upper Extrenity of it divides, and the two Portions of about a quarter of an Inch or fometimes more in Length, either both fall back in Form of a circular Arch or Hook, in an oppofite Situation to one another, or one of them only; the other remaining ftrait, and then the whole appears not unlike a Water-minn's Boat-hook.

Such is the Structure of a perfect Coffee Flower. The Progrefs of it comes next to be examin'd, from the time of its firft Appearance, wholly inclos'd in the Calix or Periantbium, till it totally wafts and decays. It is hardly ever diftinctly vifible till having broke thro' that Cafe, it thews it felf in the Shape of a white round Bloffom, the whole Flower being then wrapt up in that Manner. As it begins to unfold, the firft thing we begin to difcover further, is the forked Extremity of the Stylus, and the Explication of the whole Flower follows foon after, there being feldom above twenty four Hours between that and the Appearance of the white Bloffom: The Decay of it comes on as faft; its Prime rarely out-lafting the Space of one Day. It continues for fome time longer in a fading State, the Petalum turning infenfibly brown; and afterwards this and all the other Parts of the Flower foon vanifh and die.

We thall hear from Monf. La Roque what are the flowering Seafons of this Plant in Arabia Felix. I have never feen it flower here in England at any other time than between the End of Fune and Middle of Auguft; tho' I doubt not but that fome may ap. pear after that Month is paft.

Mr. Ray very juftly complains that no Author had given any Account of the Flower of this Plant, at the time when he wrote; and Lang us, cven after the Plant it felf had found its way to Europe, repeats the fame Complaint, and had equal Reafon for it; for till after his Lectiones - Materia Medice was publifh'd, I do not find fo much as one Obfervation about this Flower, except one mention'd by Strufius, from an Arabian Phyfician, namely, that it is white.

'The firt Defcriptions we have of it were taken from the Plants in the Amaferdam Garden; and all Authors who have mention'd it agree that it is very much akin to the Flower of the Jeffamin. From hence Commelinus deriv'd its Name; and he has likewife taken Notice of the Colomi and Smell of the Petala.

That this Flower refembles that of the Jeffamin, as much or more than any other, may be very true; but ftill there is a vaft Difparity between them. In the Jeffamin Flower the Pedunculus is twenty times longer, the united Part of the Calix much larger, 


\section{$\left(3^{8}\right)$}

larger, and the Segments only fmall Filaments or Lacinia; the Seed Veffel is quite of a different Structure; the tubulated Part of the Flower bears a much greater Proportion to the Segments in Length, and the Colour of it is rather green than white; the Segments are differently hap'd, and the Number of them much more various and uncertain. In fine, the Stamina, $A$ pices and Siylus have almort nothing in common in the two Flower's, fave only that they are defign'd for the fame Ends.

Volkamerus had an Opportunity of examining this Flower in Germany, and he has obferv'd about it, That it is of the perfect Kind; (in Oppofition, I fuppofe, to thole which Botanifts term ftamineous Flowers, called by M. Vaillant incomplete, or imperfect;) that it is extremely beautiful, and of a ftrong and agreeable Smell; that it is of the monopetalous Kind, arifing by a long Tube, and afterwards parted into five Segments; of a white Colour, and very large. Upon all which Accounts, and others likewife taken from the Fruit, he concludes that Commelinus was very much in the right to make it a Species of Jeflamin.

Thefe Obfervations relate only to the Pcta'um; but Mr. Bradley, who knew very well that the other Parts of which Flowers confift are in a philofophical Senfe the moft effential Parts of them, has not fuffer'd thefe to pals unregarded. "The - Flowers, fays he, put forth in Clufters

- at the Joints, towards the Extremities of

- the Branches, and are in Figure, Size and

- Colour, the fame with thofe of the com-

- mon Jeffamin, with the Addition only

- of five yellow Apices, which hang loofely

- on the rop of the Flower, and a Style

- which projects near half an Inch above

6 it. The Smell of the Flower, he adds,

' is faint, and not worth our Notice.
In his other Writings, he fiN infifts upon the Likenefs of this Flower to the Jerfamin; and in the lateft of them he tells us, " that every Day confirms him more and - more that the Coffee Plant is of this Tribe.

About the Time of flowering he has likewife obferv'd, that in the Amferdam Garden it begins in $\mathcal{J} u l y$, and lafts till $O_{c-}$ tober.

Monl. De Fufleu defcribes the Flowers in this Manner: "From the Ale of molt - of the Leaves arfe the Flowers, fomec times five in Number, with hort Foor- Stalks. They are all white, of one Piece, - and of equal Bignefs, very much like - to thole of the Spanifh Jeffamin, only that

- the Tube is fhorter, and the Segments

- not fo broad; the Stamina five in Num- ber, whereas our Jeflamins liave but two. - There Stamina rife above the tubulous - Part of the Flower, and furround a forked - Stylus ficuated upon the Embrio of the - Fruit or Piftillum, which lies within the

- Calis. The Calin is grcen, divided into

- four pointed Segments, the oppofite Pairs

- of which are unequal in Size. Thefe

- Flowers have a very pleafant Smell, but - are of very fhort Duration.

La Rogue, very much to the fame Purpofe, acquaints us that 'the Flowers are - white, very like the Jeflamin, confifting - of five litrle Thort Leaves (fenilles) their - Smell is very agreeable, with fomething - balfamick in it; but the Tafte is bitter. - They arife from the Place where the Foot- Stalks of the Leaves are joined to the - Branches.

6 In almoft all Seafons of the Year, continues this Author, 'there are Trees ' to be feen in Flower in Arabia; but in - that Plant which he faw at Paris, fome of - the Flowers were in bloffom only, others - perfectly blown in the beginning of Sep. - tember. 


\section{$(39)$}

\section{H A P. VIII.}

\section{The Coffee Fruit.}

70 the Flowers of the Coffee Plant, fucceds the Fruit; which, as it is the only Part of the P'ant that is ufed, will require to be treated at more Length than the reft. In order to do this with the greater Clearnefs, I have thought it convenient to throw all that I have to fay upon this Subject into three diftinct Articles; in the firft of which I thall examine the whole outward Appearance and Coverings of the Fruit; in the fecond, the Nuclei or Kernels which thefe Coverings inclofe; and in the third, the feminal Plant, or true Seed: And under each of thefe Heads I thall fubjoin fuch a Part of the hiltorical Remarks about the whole Fruit, as belongs to what is there treated. I fhould willingly have added a fourth Article, no lefs curious and entertaining than the reft, concerning the Progrefs of the Fruit from the Time that the Flower decays, and the Vafoulum feminale begins to fwell, till it arrives at a State of perfect Maturity, in which I here confider it; but in order to do that with all the Accuracy that is neceffary, I mult have deftroy'd a great many more frefh Berries than I could poffibly obtain in this Place. I have been obliged therefore to content my felf with remarking the Changes that may be perceiv'd while the Fruit remains upon the Tree; and as thefe only regard the Size and Colour of the Pericarpium or Coverings of the frefl Fruit, I have fet them down in the Article which is deftin'd for thefe.

\section{A R T. I.}

The Coverings of the Coffee Firuit.

I $\mathrm{N}$ a frefh Berry thefe Coverings may in a proper Senfe be term'd the Pericarpium of the Fruit; and therefore all that rel.tes to the outward Appearance thereof can only be taken from this. The Situation of the Fruit upon the Trees, is the fame with that of the Flower, to which it fucceeds ; only she FootStalk thoots out by degrees to a greater Length, being, when the Fruit is ripe, above a quarter of an Inch long, its green Colour ttill continuing. 


\section{$(40)$}

The Colour of the Fruit it felf is at firf green, which as it advances in Age and Size gradually changes, firft to a red, and then paffing from one degree of that Colour to another, becomes very dark by the time that the Fruit is ripe. In all States it is of an oval or f́pheroidical Figure, not unlike the Cornelian Cherry; and I never found the longeft Diameter of it to meafure much above half an Inch; nor the greateft Circumference above an Inch and an half. The tranfverfe Diameter in thefe fame Berries was about feven fixteenth Parts of an Inch; and the Circumference that way an Inch and three eighth Parts. The Weight of the whole about eight Grains.

The Pulp and Infide of the Pericarpinm is of a light red Colour, but this laft is variegated with many Streaks of white; even when the Fruit is come to Maturity; this Covcring is not very thick, and there appear no Signs then of its being lined wirn any inner Membrane; the Septum by which the two Kernels are parted, is ftill mucilaginous; and both of them are cover'd with a thick Subftance, of the fame Kind out of which the firft of the proper Coats is probably form'd by drying; the fecond being vifible already.

Thefe few Remarks concerning the Size, Appearance and Subftance of the Pericarpium, are all which it is neceffary to make about the frefh Fruit, as diftinguifh'd from the dry'd Berries. We thall fee in another Place in what manner this is perform'd; and as the chief Defign of it is that the Husks and Kernels may afterwards be eafily feparated; it is not often that we meet with many dry'd Berrics intire in thefe Parts. I have however been at Pains to pick out a confiderable Quantity from Bales of raw Coffee at the Drugfters, and fome of them I found to contain two perfect Kernels in one common Husk, others one only; I fay perfect Kernels, becaufe even in thofe that are fingle, there are moft commonly, if not always, fome Remains of the abortive Kernel lying like a Clypeus or Target upon the other, as fhall be explain'd more particularly afterwards. I have always obferv'd, that the Number of fuch entire fingle Berries in each Bale exceeded the double ones; at a Medium of all the Tryals I made, the Proportion of them was nearly as feven to one. The Reafon .why we have any entire Berries at all imported can be no other than that they are fmaller than the reft, and fo efcape the Roller which the Arabians make Ufe of to take off the Husks; and as there are fewer double Berries of that fmall Size than fingle ones, a greater Number of thefe mult remain with the Husks on. 


\section{(4I)}

Thefe two Sorts of Berries differ from one another in Figure; neither are all of each Kind entirely alike. The fingle ones are moftly of an oblong oval Figure, except where the Prominence form'd by the abortive Kernel makes a fmall Variation; the others, efpecially the fmaller Sort, are more nearly round, with a fenfible Depreffure on both Sides, running from the Foor Stalk to the other End; and by thefe Marks it may be eafily known whether a Berry be fingle or double, without taking off the Husk.

The Length of the fingle Berries I have always found between half an Inch and a quarter; the tranfverfe Circumference from an Inch to five eighth Parts; and the Weight from five Grains to one. The double ones meafur'd from three eighth Parts to a quarter of an Inch in Length; from an Inch and one eighth Part to fomething lefs than an Inch in Circumference; and weigh'd from four Grains to feven eighth Parts of one Grain ; and by thefe Dimenfions it appears that the double Berries may as eafily mifs the Roller as the fingle ones.

From this general View of the intire dry'd Berries, I go on to the Coverings in particular. Thefe are always three in Number; one common to both Kernels, and two proper to each of them. The common and outermoft Covering is only the Pericarpium dry'd; and in fome Berries it is very much thrivell'd, wrinkly, uneven, and as it were furrow'd, being of a blackifh or dark brown Colour. In others, efpecially the double Berrics, it is fmoother, and of a lighter thining brown.

The upper Extremity of this Covering, or that which is oppofite to the Foot Stalk, terminates in an Umbilious, as it is call'd by Monf. De Fuffieu, which looks as if a circular Impreffion had been made upon it, with a pretty deep Hole in the Center thereof; this Circle is nothing but the Veftige of the tubulous Part of the Flower ftill remaining, as the Hole is of the Stylus; for upon that Part of the Ovariuin they both ftood.

Upon boiling, or long fteeping in Water, this Cont becomes fo loft that it may eafily be fcrapd off; but if macerated only a little it grows thick, and may be taken off without being deftroy'd, if cut in two equal Parts; and by fo doing I have oblerved, that in many Berries it is confiderably thicker nicar the Umbilicus, thain in any other Part.

This Involucrum is always multicapfular, being divided molt commonly into two Cells or Loculamenta, as Botanifts cxprel's it; and fometimes, tho' very rarcly, into three. The Septum or Partition by which thefe Cells are form'd, may here be very diftinatly perceiv'd to be a thin fine Membrane, of a different Subftance 


\section{( $\left.4^{2}\right)$}

from the outer Coat, and dividing the Cavity of it into two equal Parts, in each of which is lodged one Kernel, involv'd in its two proper Coverings. Thro' the Middle of it, lengthways, runs a Branch or Fafciculus of ligneous Fibres, continued probably from the Foot Stalk, and ferving to convey Nourifhment to the tender Fotus. In examining the outer Coverings of fome Berries, I have been often inclined to believe that the whole Cavity of them was lined with an inner Membrane, really diftinct from the pulpy Part of the Coat; and perhaps this Septum may be only a Production or Elongation thereof, continued on both Sides to the Fafciculus of Fibres already mention'd: But whatever Way it be form'd, as it adheres infeparably to thefe Fibres it has all the Properties of a true Partition, and therefore the Sced Veffel it felf is certainly multicapfular. In thofe I have for Diftinction's fake call'd fingle Berries, this Septum is ftill to be feen between the abortive Kernel and the other; but then it no longer occupies the Middle of the Cavity, but is thruft out of its Place, and by that means very much impair'd.

The fecond Covering, or firft of the proper Coats, may be truly reckon'd a Cortex or Shell, being very ftrong and hard, but withal very brittle; and, if I miftake not, the Confiftence of it mult be in a great meafure owing to the drying of the Berries, for in all the frefh Berries I ever had an Opportunity of examining, it was foft and mucilaginous. I am furprized that they who contend that the Coffee Fruit is of the Nut Kind, as diftinguifh'd from a Berry, have not made ufe of this Coat to prove it. The Difficulty it felf is indeed a meer trifling about Words; the Signification of thefe Terms Nut and Berry, being, as far as I can find, hitherto unfettled among Botanifts.

Since this is a proper Coat, it mult either be continued over the Sulcus or Rima in each Kernel, or terminate at both Sides, fomewhere on the Edges of it. Which of thefe is true in fact, I cannot with Certainty determine; I am apt to imagine the laft; and that therefore by means of this Sulcus, the Fibres in the Septum always placed oppofite to it, may have fome Communication with the Kernel it felf, or at leaft with the inner Covering of it.

The Colour of this fecond or cortical Coat, is moftly that of a Limon, only a little more inclined to red, and the Figure of it always the fame with the Kernel it inclofes.

The third or innermot Covering, which becaufe of its Colour may be call'd the Silver Coat, is made up of a very fine thin Membrane, furrounding not only the outfide of the Kernel, but 


\section{( 43 )}

alfe the Procefs which lies in the Cavity of it, as thall be prefently thewn. The two Sides of it enter the Sulcus of the Kernel, and there jointly form a double Lamina, which is from thence continued quite over the Procefs; and to that, as well as to the reft of the Kernel, this Coat adheres very clofe. I have never been able to diftinguifh either of thefe Coats in an abortive Kernel.

The molt ancient Author by whom I find the Coffee Fruit mention'd, is Ramzolfius, who was in the Levant in 1573 , and he has obferv'd, that both in Bignefs, Shape and Colour, it is like the Bay Berry. It is the dry'd Fruit Ranzvolfus here talks of, and the Comparifon he makes of thefe to the Bay Berries, is not much amifs, only thefe laft are commonly larger than the entire Coffee Berries we meer with in thefe Parts. He adds, that the Fruit is furrounded by two thin Shells, which contain two Grains in two diftinct Cells. Thefe two Shells are probably the common and firft of the outer Coats; which are all that have been taken Notice of by any Writer fince his Time. What he has faid about the two Cells is very indiftinet, and yet it is more than has been faid by any Body fince.

Next to Ranvolfius, is Profper Alpinus, who was in Egypt in 1580; what he has faid about the Coffee Fruit is but very little, neither is it certain whether he means the entire Berry, or the Kernel only.

Clufins has obferved upon this Subject, that the Coffee Fruit is fmall, yet fomething bigger and more oblong than that of the Fagara, with a kind of Sulcus running lengthwife on both Sides of it, being cover'd with a thin Cortex of a dark afh Colour.

Gerrard has done nothing but copy Clufins's Figures, which he has placed by Miftake among the Indian Fruits; and Fobnfon, in his Editions, has added Clufuru's Text to his Figures.

F. $B$. tells us that this Fruit is hardly bigger than the Seeds of the Ricinus, of the Shape of an Olive, with a Sulcus or Lacuna, fometimes on one Side, fometimes on both. By this laft can only be underflood, that the Depreffure is not always alike perceivable on both Sides of the Fruit. This Author has likewife taken notice that the Fruit confifts of two Shells, whereof the outermoft is thick and black; the other thin, and red on that Side which lies next the Kernel, on the upper Side of an an Colour.

Petrus de la Valle fays only, that the Grains of which Coffee is made are of an oval Figure, and about the Bignefs of a fmall Olive. And Olearius compares the Size of it to that of a fmall Bean.

$V$ eflingius informs us of the Difference he had obferv'd in Egypt between the Tafte of the Coverings and that of the Kernel: The firft, he fays, is in fome Degree acid, the other very fenfibly bitter. This Diftinction we need not be very follicitous about, for in however great Requelt the Shells may be in Arabia Felix, and the Countries which lie near it, on account of the $\mathrm{Li}$ quor there made of them, call'd by way of Excellency, Café a la Sultane; yet but a fmall Quantity of them ever comes into Europe, and before they get hither they have pretty much loft their Tafte, and every other fenfible Quality that is worth minding about them.

According to Parkinfon, the Coffee Fruic is fomewhat bigger than a hazel Nut, and longer, round alfo and pointed at one End, furrow'd alfo on both Sides, yet on one Side more confpicuounly than on the other. He tells us likewife, that the outer Coat is a thin Shell of a darkin an Colour, and the other he calls a yellowifn Skin. All this thews plainly enough that Parkingon had feen the Coffee Fruit, but withal, that he had been at very little Pains to examine it.

Banefus affures us, that the intire Fruit is fomething like the Cacao, but cleft along the Middle like a date Stone, and cover'd by a Shell or Husk.

Dr. Grew has faid nothing about the Coffee Fruit in particular; but fince, by what we thall fee afterwards, he appears to have examin'd it very exactly; and has often declar'd, that in the far greareft Part of Seeds there are three Involucra, it is reafonable to fuppofe that all thofe I have defcrib'd were known to him.

Dr. Robinfon, in his Letter to Mr. Ray, informs us that the intire Fruit is round on one Side, and flat on the other; but what we have principally to remark from this otherwife judicious Botanift, is the Manner in which he endeavours to prove that this Fruit is of the Nut Kind, in which I think he has come very far thort of his ufual Accuracy: " The intire Fruit, fays he, is cos ver'd with two Skins; the exterior Skin, 


\section{$(44)$}

- or rather Shell (being as thick almoft as " that of a Pijtacbio) is of a dark Colour; - the fecond, or interior Membrane, that - covers the Kernels is much finer, and of - a yellowin white Colour. Under this - fecond Skin lie generally two Kernels, - fometimes one.

What Part of this Nut ought to be reckon'd the Kernel is eafily determin'd: As for the Shell, I have already taken Notice, that the firft of the proper Coats feems beft to anfwer that: Dr. Robinfon has chofen the common or outer Coit, and he is in the right to fay it is almoft as thick as that of the Piftachoe; but then, if I am not miftaken, it is not by virtue of that outer Coat that the Piftachoe is call'd a Nut, but on account of a hard Shell that lies under it, to which the outer Coat of the Coffee Fruit has no Refemblance, neither in Subftance nor Situation. By what he fays further, that under this fecond Skin lie generally two Kernels, it would feem that he look'd upon it not as a properbut as a com. mon Coat, as much as the other; but how this can be, I do not fo well underftand, fince not only each Kernel in particular is quite furrounded by this Coat; but being thus involv'd, is intirely feparated from the other by means of the Septum. In fine, by the Date of this Letter it appears that it was written the Year before the fecond Volume of Mr. Ray's Hiftory of Plants was publifh'd ; and therefore it may feem ftrange, that after all the Pains this Author had been at, he fhould nor have been able to perfuade his Correfpondent to rank his Coffee Frutex not among the bacciferous Plants, as he has done, but among the nuciferous. The Difference however lay, probably, in the Ufe of a Word only, Mr. Ray's Arbores nucifere fructus per maturitatem jicco, being, as he himfelf informs us, in every thing, except in Size, the fame with the Baccifere of that kind.

What I have hitherto remarl' $d$ concerning the Refemblance of the Coffee Fruit to a Nut, mult be underftood of the dry Berries only; for in the fren Fruit all the Coverings are fo perfectly foft and pulpy, that they can in no Senfe, neither fingly nor together, be faid to form a Shell. And whether a Fruit, which while it hangs upon the Tree is certainly not a Nut, can afterwards, by drying, be changed into one, I leave to thofe who are better vers'd than $I$ in fuch Diftinctions, to determine.

There is nothing but Repetitions to be met with in the other Author, before the Year 1694, in which Sir Hans Sloane informs us that the Fruic comes out $c x$ alis foliorum, hanging or flicking to the Twigs

by Inch-long Stripgs or Foot-Stalks; and fometimes one, two or more at the fame Place.

Both Lemerys obferve that this is a fmall longin Fruit, round like a Pignon (which I fuppofe to be the Seed of the Ricinus $A$ mericanus) and that the Cortex is a pretty hard ligneous Husk.

In Tournefort's pofthumous Treatife of the Mattria Medica, we are told that the Seeds are inclofed in Husks; for the molt part confifting but of one Cell, fometimes of two. By this I fuppofe the Author means no more, than that for the moft part each Husk contains but one Seed. This is true with refpect to the intire Coffee Fruit that is imported into Europe : but with respect to all the Coffee Fruit produced in Arabia Felix, juft the contrary is to be faid.

Volkamerss, who had feen the Coffee Plant in a bearing State, tells us that the Fruit confilts of two Kernels lying upon one another, included in a juicy Pericarpium; and from thence he concludes that the Plant ir felf ought to be ranked among the bacciferous Kind.

Mr. Bradley, in his firft Treatife, obferves, that a about OEtober thefe Trees have c done blowing, and then they are comc monly well fet with green Fruit, which - hang on them till the Fuly following be- fore they are ripe; they refemble at that - time the Berries of the Lauro Cerafus, or - Bay Cherry, and are much of the fame - Shape and Colour, (i.e. of a dark red) - but inftead of a fingle Stone, thefe have " two Kernels which fplit in the Middle, ' like the Bay Berries of the Shops.' He has faid nothing further about the Coffee Fruit in any of his later Works.

What belongs to this Article, from $M$. De Feflew is, That ' the Embrio or young - Fruit grows nearly to the Bignefs of a - Heart-Cherry, and is pretty much of the - fame Figure with it; but that when it is - perfectly ripe and dry, it is reduced to - the Size of a Laurel Berry. The Fruit - ends in an Vmbilicus, being at firft of a - light green Colour, then reddin ; after- wards of a very beautiful red, and when ' perfealy ripe, of a dark red. The Pulp ' is glairous, or mucilaginous, of an un- plcafant Tafte, and when dried becomes - like that of a black Prune. Under this - Pulp lie two thin oval Coats, clofely ad- hering together, convex on one Side, and - flat on the other, by which they touch; - and of a yellowith white Colour.

Monf. La Rogue, much to the fame Purpofe, acquaints us, that ' to every Flower ' fucceeds a fmall Fruit, but which by de-

$$
\text { I. } \quad \text { gres }
$$




\section{(45)}

- grees grotws to the Size of a large Cher- ' Husk of a dark brown Colour, which

- ry, in which State it is very good to " makes the firft or outer Cortex of the

- eat. It adheres to the Tree by a fmall - Coffee Bean, and within it lies another

- Thort Foot-Stalk, and when perfeetly ' thin Membrane, which makes the fecond

- ripe is not much bigger than a Laurel Ber- 6 or inner Cortex.

- ry. It comes out between the Leaves M. Millerhas only told us, ' that in the

- and Branches. At firlt it is green, bue - Coffee Plant the Flowers are fucceeded by

- grows red as it ripens; and the Sun hav- "Berries, and that each Berry includes two

c Ing dry'd this red Pulp, it becomes a S Seeds in an inner thin Skin.

\section{A R T. II.}

\section{The Kernels of the Coffee Fruit.}

A L L the Coverings defcrib'd in the laft Article being remov'd, 1 the Kernel it feif comes next to be examin'd; the Colour of which, to begin by that, varies according to the Frefhnefs, Goodnefs, and Place of Growth of the Berry; fome of them have a Calt of green, fome are whitifh, fome dark or brown, and if damaged by falt Water, they are perfectly black.

The Figure of the Kernels varies likewife; but that is principally determin'd by the Number of them in the fame Berry. The fingle ones, filling up the whole Cavity, have Liberty to extend themfelves on all Sides, and confequently the Figure of them is that of a longifh Oval, with a Cleft on one Side, upon which lies the abortive Kernel, as has been already faid, in Form of a Clypeus or Target, very thin, and of a circular Figure, a little deprefs'd on one Side, to accommodate it felf to the other. The double Kernels, for the fame Reafon, are nearly oblong Hemifpheroids, being convex on the back Side, and flat on that by which they join one another; and in moft of them it may be remark'd that they are a fmall matter bigger at one End than at the other. Thro' the Middle of the flat Side of each, runs a Sulcus or Rima lengthwife, generally narrower than that of the lingle Berries. The Figure of the triple Kernels is likewife to be determin'd by their Situation in the Seed Veffel; but of fuch I believe very few are to be found.

The far greateft Part of the Coffee that is imported into Europe, confilts of fuch Kernels as have been double in the fame Fruit, and the Dimenfions and Weight of all the Kinds thereof may be guef'd at by thofe taken at a Medium from the Kernels that are brought us by the Way of Turkey, and thofe that come from fava in the Eaft Indies. The greateft Length of the firft Sort is three eighth Parts of an Inch, Breadth one eighth Part, and Weight three Grains. Of the fava Coffee I found the 


\section{(46)}

Length to be half an Inch, Breadth five fixteenth Parts, and Weight five Grains and an half.

The principal Body of each Kernel confints of an hard, callous, cartilage-like uniform Subftance, made up of two Lamine, firft laid one upon another, and then rolled and folded up into the Figure we have juft now defcrib'd. Whoever views a tranfverfe Section of a Kernel, the firft Idea of its Structure that prefents it felf to him will be undoubtedly that of a Body rowl'd up, as I have faid; but I think a more eafy Way to conceive that fully, will be firft to imagine two oblong hollow Hemifpheroids cafed clofely over one another, and cover'd with a Lid flit thro' the Middle lengthwife; and then that this Cavity is fill'd up by another Body, adhering to or proceeding from the whole under Part of one Side of the Lid, but loofe from the other, under which the Edge of it is turn'd up, fo as to form a new kind of Sulcus', continuous with the former, tho' not always in the fame right Line. This inner Body I know no better Way to exprefs, than by calling it a Process arifing from one Side of the Slit or Sulcus fo often mention'd. The Structure of a fingle Kernel is to be conceiv'd much after the fame manner, only here the Slit is generally wider, the two Sides of it being not flat, but convex; and fo appear rather to be a Continuation of the fame Figure with that of the Backfide of the Kernel, than as a Lid laid over a Cavity. By this means likewife, the Figure of the Cavity varies, and that of the Procefs along with it. In every thing elfe the Structure of both Kinds of Kernels is the fame: And I have only thefe two Things further to obferve about them.

Firft, that the two Lamina of which they are compos'd, are not every where of the fame Thicknefs; from whence it follows, that one Side of the Cavity is fometimes thallower than the other. In the next Place, the Procefs does not always come out from the fame Side of the Sulcus; or, which is the fame thing, the Kernel is not always rowl'd up one Way. By which I mean, that the Situation of all the Parts of the Kernel being once determin'd by that of the feminal Plant, (of which in the next Article,) the Procefs will be found to adhere fometimes to the right Side of the Sulcus, and fometimes to the left.

Ramuolfius has taken Notice only of the Colour of the Kernels, and that, he fays, is yellowin.

From Alpinus we learn, that the Kernels he found in Egypt were of a fweet Tafte, mix'd with a little Bitternefs, but no Sharpnefs. Whether he was altogether in the right in this, I leave to every Body's Experience to refolve them.
Clufius tells us that they are of a darkin yellow Colour, acid Tafte, and flat on one Side.

F. $B$. that 'the Coverings being remov'd; ' there appears a hard Kernel, much of the - Shape of a date Stone, with an hollow run' ning thro' it lengthwife; of a pale an $\mathrm{Co}-$ - lour, and a bitrer unpleafant Tafte; and that 


\section{(47)}

- that all the way from the Umbilicus to the

- oppofite Point, it appears as if it were di-

- vided into two Grains (ab umbilico ad oppofitum mucronem gemina offentat grana.) From the whole of what we have quoted from this Author, both here and in the laft Article, it appears plainly that his Defcription was taken from a Fruit with only one Kernel; and therefore it is not eafy to guefs the Meaning of the laft Words of it. Confidering the Place where they lie, I thould be inclin'd to think they were added by the Editors, for they are no ways of a Piece with the reft; but if they do really belong to Baubinis's Text, I can make no more of them than this, That when a fingle Kernel is view'd on that Side on which the Sulcus lies, it appears as if it were divided into two Grains.

But whatever be the true Meaning of them, I can find nothing in all this Defcription that contradicts what we have heard from Clinfus; and therefore I cannot imagine the Reafon why $\mathcal{F}$. $B$. Mould add, that tho' the outward Appearance of this Fruit anfwer'd in every thing to the Figures given us by Clufurs, yet there were other things in which they did not agree; and that therefore he durft not fay that his was the fame with that from whence Clufius's Figures were taken. It may. be his Scruple was grounded on this, that Clufsus's Berries were double, and his own fingle.

By Olearius the Colour of the Coffee Kernel is compar'd to that of common Wheat, and the Tafte to that of Turkey Wheat:

We have heard already, that according to Veflingius the Tafte of them is very fenfibly bitter.

Parkinfon informs us, that on each Side of the Husk of the Coffee Fruit lieth a fmall long white Kernel; flat on that Side they join together, of an acid Tafte; and fomewhat bitter withal.

Banefius diftinguinhes the Coffee Kernels into two Sorts, with refpect to their Colour ; one he fays is whitifh, the other of a darkin Citron Colour, tending towards a green; and thefe laft are to be preferr'd to the firft. All this is true enough in fact; but it feems to be owing to our Author's not having underftood Avicerina, that ever he was fo lucky as to obferve it. Avicenna has told us the fame thing of a Root which he calls Bunchum, and this Banefius and others, as we thall afterwards hear, have niftaken for the Buna or Coffee Fruit.

The curious Enquiries which the learned Dr. Grews made concerning the Seeds, as well as all the other Parts of Plants, have furnifh'd him with fome very uncommon

Obfervations concerning the Coffee Fruic in particular, befides what he has faid about other Seeds, which will equally agree to it:- Thefe laft I leave to be confulted in his excellent Anatomy of Plants; the others mult not be omitted liere. Having defcrib'd the Coverings that belong to Seeds, which he proves, in the greateft Part of them, to be three in Number, he obferves, that in many there is a Vitellum or Body analogous thereto, which is neither Part of the true Seed, nor Part of the Covers; but diftinct from them both. This he tells us makes fometimes the principal Part of the Fruit, being much bigger than the true Seed it felf; and in enumerating the different Figures, Difpofitions, and other Properties of thefe Vitella, among the reft he obferves, that in Goofegrafs or Cliver it is of a horny Subftance, but fhap'd fomewhat like a Bonet with the Rims tuck'd in; and fo in the Coffee Berry, but rowl'd or folded up into a kind of oval Figure, with a Notch or Rima running thro' the Length, where the two Ends meet. This Paffage contains the only Hine that is to be met with in Authors concerning the true Structure of the Coffee Kernel; and I hope it. will be ftill better underftood by the Account $I$ now give of it.

Dr. Robinfon has obferv'd but little about thefe Kernels; under the fecond Skin, he fays, lie generally two Kernels, fometimes one, round on one Side and flat on the other. On the flat Side of the Kernel there is always a Slit or Mouth; fo that every Kernel does exactly refemble a Concha veneris.

Lemery compares the two together to a young Pea in Bignefs; and fays further, that they are of an oval Figure, eafily parting into two Halves; of a yellowin $\mathrm{Co}$. lour, with a Caft of white. Tafte.

Lanigius fays the Kernel is of a mealy.

Tournefort, that the Seeds are hard, of a whition an Colour, convex on one Side; flat on the other, and furrow'd; of a mealy Tafte, and without any Smell; five or fix Lines in Length, and three in Thicknefs.

Chomel and Andry agree in every thing with Tournefort; only the laft adds; that thefe Seeds are very heavy in proportion to their Bulk.

Mr. Bradley; as we have already heard, has obferv'd that the Coffee Fruit has two Kernels, which fplit in the Middle, like the Bay Berries of the Shops. It is true, the Coffee Kernels do fplit in the Middle, and fo do the Bay Berries of the Shops; but wherein the Likenefs of their fplitting confifts, I thould be glad to learn.

M. DG 


\section{$\left(4^{8}\right)$}

M.iDe Fufiers's Obfervations about the Kernels are thefe: "In each of the inner - Coats is contain'd a callous oval Seed, - arched on the back Side, and flat on the c other, in the Middle of which is a pretty

- deep Sulcus running thro' its wholeLength.

- Sometimes one of thefe Seeds proves a-

- bortive, and then the other grows com-

- monly bigger than it would otherwife

- have been; both Sides of it become more

- convex, and it fills up the whole Cavity

s of the Fruit.

Monf. La Rogue has added fome new Obfervations ftill, concerning the Progrefs or gradual Formation of thefe Kernels: - Under the Pulp, fays he, lies the Bean or

- Grain which we call Coffee ; and even

- when the Fruit has arriv'd at its full

: Bignefs the Bean is extremely tender, and
- of a difagreeable Tafte; but as the Fruat

- ripens, it acquires by degrees a little more

- Solidity; and by the time that the Pulp

- is nearly dried up, the Bean is become

- pretty hard, and of a light green Colour,

- fwimming in a thick brown and bitter

- Liquor.

Valentini tells us, that ' what is call'd Cof-

- fee, is nothing but the Kernels of certain

- Imall Nuts, confifting of two Parts, like

- Beans, arch'd on the upper Side, flat and

- furrow'd on the other; of a dark yellow

- Colour, mealy Tafte, and Smell like that

- of burnt Beans. It is Pity this Author did not add, that it was the Smell of roafted Coffee he meant, and then the Comparifon would not be amifs; neither are thefe two much different in Virtues, if we may. believe the learned Doctor Cheyne.

A R T. III.

The Seminal Plant, or true Coffee Seed.

$\mathrm{W}$ E have heard from Dr. Grew, that the main Body of the Kernel defcrib'd in the laft Article, is not the true Seed, but only a Vitellum or Body analogous thereto; which he fometimes. likewife calls the bulky or cartilaginous Cover of the Seed. As he is the only Author who has obferv'd this Difference, fo none but he has defcrib'd what the true Seed, as diftinguifh'd from the Vitellum, really is. "The Fotus, or true Seed in the Coffee Ber' ry, fays he, lies in the inner or cartilaginous Cover, where one - would not expect to find it, near the Top or Surface of the - Back. The Lobes of the Seed are vein'd like two very minute - Leaves, and join'd to a long Root like a Stalk, the End of " which comes jult to the Bottom of the Cover, ready for its " Exit into the Ground." All this he has exprefs'd by five Figures in Tab. 77. of his Anatomy of Plants; whereof the firft exhibits the hilly or furrow'd Side of the Coffee Berry; the fecond, the Back; the third, the Back par'd a little, fo as that the true Seed may appear in fitu; the fourth, reprefents the true Seed taken our of the Kernel; and the fifth hews it very much magnify'd.

This is the Account which Dr. Grew has given us of the true Seed, (or, as it is call'd by Malpighi, and others fince his Time, the Seminal Plant) of the Coffee Fruit; and whoever is acquainted with Dr. Grew's Writings, knows, that according to him, in every Seminal Plant may be diftinguifh'd the Radicle, Lobes and Plume. This Remark was neceffary in order to the underftand- 


\section{$(49)$}

ing of fome Terms which I hall be obliged to make ufe of in explaining what farther Obfervarions I have'made, both concerning the Situation and Strufeure of the Seminal Plant.

It lies between the two Lamelle of the Vitellum or Body juft now defcrib'd, in a Bed exactly fitted to it; the Radicle always terminating at the Extremity of the Sulcus, which in an entire Kernel may be difcover'd by a round Speck, of a different Colour from the reft of the Surface. As the Back of the Kernel is convex, the Seminal Plant, to accommodate it felf to that Figure, is likewife bent upwards, and fo lies crooked. The Pofition of it is not exactly according to the Length of the Kernel, or parallel to the longeft Diameter of it, but oblique; it being all on one Side of the Rima (as may be feen by Candle-light, even with the naked Eye) in an entire macerated Kernel. It is not, howcver, always on the fame Side, but fometimes on the right, fometimes on the left; and yet this Pofition is no ways cafual, but regulated by the Rowl or Fold of the Berry; that is, the Seminal Plant lies always on that Side of the Sulcus to which the Process is fix'd.

When it is carefully taken out of the Kernel, the Figure of it refembles nothing fo much as the Ace of Spades in Cards, only the Radicle is longer in proportion to the Lobes, than the Handle of that Spade is commonly made. The Colour of it appears then lighter than that of the Kernel. And the Radicle or little Root, as far as I can perceive, is exactly round, and runs tapering from one End to the other; that to which the Lobes adhere being fmalleft, as is well exprefs'd in one of Dr. Grew's Figures. The Lobes or Leaves may eafily be feparated from one another all the Way to their Infertion into the Radicle; but nothing like a Plume is difcernible betwixt them.

I have only further to remark, that in the Situation of this Seminal Plant, as well as in the whole Structure of the Kernel, the Wifdom and Contrivance of Nature is very difcernible. The Extremity of the Radicle is placed in the weakelt Part of the whole Kernel, and confequently finds the cafieft Paffage poffible into the Ground; the two Lamelle are there, as it were, only tuck'd in; and thus fmall Rime or Chinks mult neceffarily be left, which in dry'd Kernels we fee oftentimes increas'd to very fenfible Clefts: Befides, upon the leaft Swelling of the Kernel in the Ground, thefe Folds mult extend themfelves, and by this means likewife favour the Exit of the Radicle. Again, by the oblique Situation of the whole Seminal Plant, and always on that Side to which the Procefs is fix'd, they lie in the molt fecure Part of the whole 


\section{$(50)$}

Kernel, which would have been quite otherwife had they lain ftrait, and fo over the Sulcus. In fine, the Kernel it felf is roll'd up in the manner we fee it, not only for the Security of the Seminal Plant, but alfo that it may unfold by more eafy Degrees, according as the Lobes and Plume are ready to expand themfelves. The firft of thefe Ends accounts likewife for the Neceffity of the Procefs, the fecond for that of the Rima or Sulcus, and both of them for the Conveniency of a double Lamina in the Kernels. But as this unfolding will require Time, the Radicle probably gets a very fure Footing in the Ground, before the Seminal Leaves, reach the Surface of it.

\section{H A P. IX. \\ The Culture of the Coffee Plant in England.}

$\mathrm{H}$ Aving already publifh'd an Account of the Management of this Plant in its native Country, Arabia Felix, I thall here confine my felf to the Culture of it in the Weftern and efpecially in the Northern Parts of Europe, the Directions to be obferv'd herein being what it principally concerns us to be acquainted with. Very little has been publin'd on this Subject by any Author except Mr. Bradley, whofe Obfervations I thall give in the fame Order in which they appear'd; to thefe I thall fubjoin the few Remarks which have been made by other Botanifts; and then conclude with a Paper of Inftructions communicated to me by an ingenious Gardiner, Mr. Thomas Knowlton, founded entirely on his own Experience.

In his firtt Treatife on Coffee, Mr. Bradley tells us, that ' the - Coffee Plant having now found its Way into England, it may r be neceffary to offer fome proper Directions for its Culture, c agreeable with the Method obfervable in the Amfterdam Gar' den. When we fhall have an Opportunity to propagate thefe ' Trees from the Berries, we muft then, immediately after they ' are gather'd, carefully take off the outfide Husk, and feparate ' the two Seeds which are found in each; clean them from the 'Pulp, and fet them an Inch deep in Pots of fine Earth, which ' are already warm in a Bed prepar'd with Horfe-litter, keeping 


\section{( $\left.5^{\mathrm{I}}\right)$}

' the Glaffes clofe cover'd for fix Weeks, and often fprinkling

' them with Water. From this Way of Management we may

- expect them to come up in lefs than two Months Time after ' fowing. And then for their further Improvement, you are

' only to remark, they love Warmth, little Air, a light fandy

' Earth, and much Water; and this laft Hint anfwers to an Ob-

- fervation of that great Naturalift Dr. Sloane, where he tells us

- That the Arabians cut artificial Channels from the Rivers, on purpofe

‘ to nourifh thefe Plants. Thefe Rules being well obferv'd, we

- may expect them to bear Fruit in five Years Time from the

' putting in of the Seed.

From his Nerw Improvements in Planting and Gardening, we learn, that ' in the Culture of this Plant the Dutch Gardiners ' prepare a Soil for it compos'd chiefly of Sand; and the Re-

- frefhings they give it with Water are feldom and fparing in the

- Winter, but in the Summer it has a more plentiful Allowance,

- efpecially during the Time of its Bloffom. About Fune they

' take it out of the Houfe, and warh and cleanfe the Leaves and

- Branches, and letting it remain in the Air till the Beginning

- of $\mathcal{F u l y ,}$, they then fet it again in the Confervatory for flower-

' ing. In April and Auguft they give fresh Earth to the Plants,

' and they thrive extremely. In raifing thefe Plants from the

- Seeds, they firft feparate the Kernels in each Seed, and after

- they are clean'd from the Mucilage abour them they are imme-

- diately fet two Inches deep in Pots fill'd with fandy Soil, and

' plung'd into Hot-beds. The Seeds, being thus order'd, muft

s be kept moilt by frequent Sprinklings of Water, till they come

' up, and the Glaffes over them always kept clo?e. About

- fix Weeks after fowing they will begin to appear, and have

' two or three Leaves apiece before Winter. I have heard that

- unlefs the Seeds are fown as foon as gather'd, they will not

' come up; and hitherto there is no other Way known of pro-

' pagating this Plant, but from Seeds: Tho' I think it would not

- be againft Reafon to try to inarch it upon fome other Kind of

'Jafmin.

In the fecond Edition of his Treatife of Coffee, I find nothing material added to what we have fet down from the firft; but in his Montbly Treatifes he has enlarg'd upon this Subject in feveral Places: The Sum of all he has faid comes to this, That ' in - the Amfterdam Gardens the Coffee Trees are kept conftantly in ' a Glafs Cafe, which as near as I can guefs, fays he, is about

' fiftcen Foot long, and about twelve Foot wide; the Height ' about twenty Foot; the Front is all Glafs; under the Floor is 


\section{$\left(5^{2}\right)$}

- an Oven for Fire, which leads into Flues, that after their Paf-

' fage here and there, end in a Chimney, as oiher Stoves do.

- They ufe no Tanners Bark in this Houfe, nor give the Plants

' any Air all the Summer, but thro' little Calements about a

' Foot fquare, placed about the Middle of the great Windows

' or Pannels of Glafs; and cven thefe little Calements are fel-

' dom open'd, becaule there is a Door which opens out of this

- Glafs Cafe into a large Greenhoufe, which they commonly

' keep open in the Summer-time. Their Earth is very light.

- They begin to make the Fires in the Stoves in October, and con-

' tinue it conftantly till the Weather is warm cnough in the

' Spring for the Plant. I fuppole this continued Fire in the

- Stoves is neceffary to continue the Growth of the Plants, when

' the Juices are once flowing; for to warm the Houfe one Day,

' and let it cool the next, will certainly check the Growth of

' a Plant.

' It is obfervable, that when the Fruit is ripe, about the Be-

- ginning of Fuly, it mutt be gather'd, and immediately the

' Seeds mut be clear'd from the Pulp, and fet in the Ground,

' otherwife they will not fprout. This Particular the Gardiner

' at Amfterdam, Mr. Cornelius, obferves diligcntly, and tho' I fent

' fome Berries frefh gather'd, by the Polt, which were not above

- four Days in their Paflage to London, to a very great Artift,

' they could not be made to grow; but when they are fet imme-

' diately, he tells us, that even in the natural Earth, he has feen

- fome Coffee Plants above Ground within three Weeks after the

- Seed was put in the Ground; but then they mult not be put

' in promifcuouly in a Body of Earth, but planted an Inch or

' two deep in it. It is a Cuftom there, twice or thrice in a

- Summer to clean the Leaves of the Coffee Plants with wet

- Spunges, which takes off the Duft that ftops the Pores of the

- Leaves. This I look upon to be of confiderable Ufe, becaufe

- I fuppofe the Leaves to receive fome Nourifhment from the

- Air, which circulates about them; and confequently the whole

' Plant is benefited by it. I obferv'd likewife, that the Gardiner

' there gave them frequent Watcrings, a little at a time, becaufe

' the Earth was very light; but efpecially in the Summer, when

' the green Fruit was towards ripening, he gave them more Wa-

- ter than at orher times, that is towards fune.

Mr. Bradley's lateft Obfervations on the Culture of the Coffee Plant are contain'd in his Appendix to bis Nerv Improvements :

' I thall proceed, fays he, to remark fome Particulars relating to

' its Culture, which yet are not made publick. I have already 


\section{$(53)$}

' given my Reafons why I fuppofe it to be a Feffamine; and have in my New Improvements prefcrib'd the inarching of it - upon the common Jeffamine, as we do the Plant commonly

' known by the Name of the Arabian Feffamine, which I am per- fuaded will do very well, fince every Day confirms me more

' and more that it is of that Tribe; however, I have heard from

- Mr. Knowlton, who was lately Gardiner to Dr. Sherrard, that ' in the Doetor's curious Gardens at Eltham, he rais'd the Coffee

- Trees both by Layers and Cuttings; fo that if there may be - fome Difficulty in raifing it from the Berry, there will be none ' in raifing or propagating of it thefe Ways.

- But there is one thing which ftill remains to be mention'd ' concerning the Management of the Coffee Tree, which I have

' only Mightly touch'd upon in my New Improvements; and

- that is, the Neceflity of wafhing the Leaves and Shoots about

- Gune, and even in September too. This mult be done with a

' Spunge and Water, and if there is fome Tobacco ftecp'd in the

- Water, I believe it will do good, for I find that the Leaves

' and Stalks of the Coffee Tree are apt to be cover'd, about

- Fune and $f u l y$, with a kind of Mildew, fuch as may be ob-

- ferv'd on the Flower Stalks of Collyfiowers, which afterwards

- changes to little Infects that will poifon the Plant; thefe there-

- fore fhould be carefully wafh'd off as foon as we difcover them,

' and is what is very ftrictly obferv'd by the Gardiners in Holland,

' not only in this Cafe, but in the Culture of every Stove Plant.

- They have People on purpole to clean the Leaves of their Houfe

- Plants, but more frequently the Coffee Tree than any other;

' and no Plants look better than theirs. I remember M. Corne-

- lius, the curious Gardiner at the Phyfick Garden at Amfterdam,

- fer fome Seeds of the Coffee in a Pot which ftood abroad, and

' they came up, and made as good an Appearance as any of thofe

" that were rais'd in the Bark Bed.

By thefe different Steps has Mr. Bradley arriv'd at that Degree of Infight into the true Method of cultivating the Coffee Tree, which he is at prefent Mafter of. His Knowledge thereof he owns to be owing, in a great meafure, to what he obferv'd in the Amfterdam Garden; but what I wonder at is, that in his lateft Performances thefe Obfervations do not always agree with thofe publin'd in the former, 'that is nearer the time in which he had made them. For fome Things likewife he has been oblig'd to M. Knowlton, whofe Thoughts upon this Subject we fhall hear prefently at more Length, after we have mention'd a few Remarks more concerning the Culcure of this Plant, from Meffieurs De fuffieu and Tilli. 


\section{( 54 )}

The firft of thefe Authors has told us only, that if the Seecis are not immediately fet as foon as gather'd, they will never germinate; and that of this he has had feveral Proofs himfelf from Tryals made in the Royal Garden at Paris.

Tilli remarks further, That in the Garden of Pi a, during the Month of Auguft, he has ventur'd to take this Plant out of the Stove, and fet it under the Shade of fome other Tree in the open Air, and that it was fo far from fuffering any Damage, that it throve the better for fo doing.

M. Knowlton's Account of the Culture of the Coffee Plant, is in a Letter dated at Petworth in Suffex, Feb. 4. 1725-6, and befides the Difcoveries it contains, it deferves to be valued for this Reafon likewife, becaufe the Directions he gives are all taken from his own Experience of what he found to anfwer beft, not from Conjectures and Hear-fay only. They may therefore be fecurely depended on by all who have a mind to cultivate this Plant in England.

'In the latter End of $f u l y, 1723$, fays he, the worthy Doctor

' Sherrard (with whofe Brother I then liv'd) brought over from

- the Phylick Garden of Amfterdam, one Coffee Tree of about

- three Foot high, and one Berry. The Berry, carefully co-

- ver'd over with Wax, was given to me, with fome Directions

' relating to the Culture of it, from Cornelius Vofs, Gardiner at

- Amfterdam; but thefe being no ways agrecable to my own No-

- tion, nor to the Practice of Gardening here in England, I begg'd

' Leave to ufe my own Skill, without being confin'd to them.

- The Berry being open'd, parted into two Seeds, and having

' prepar'd a good frefh rich fandy Soil, I put them into a fmall

- Pot fill'd therewith, about two Inches deep, and immediately

' after plung'd the Pot into a temperate Hot-bed. In about four

' or five Weeks afterwards I had the Pleafure of feeing one of

' them come up, with his Cap on his Head; and the other fol-

' low'd in a Week afterwards. They continu'd growing very faft

' both Winter and Summer alike, and in a Twelvemonth's Time

' were above two Foot high.

' Having now three Trees in good Health, I refolv'd to try

- fome Experiments relating to the Culture and Propagation of

' this Plant. The firft was an Inarchment on the yellow Indian

- Jeffamin, and likewife on the Arabian and Brafle white Jeffa-

' min; but all three without Succefs, tho' repeated each of them

' twice over. The next was to make an Incifion at a Joint, and

- to lay four Branches down in the fame Soil in which the Trees

- were planted. This fucceeded very well, for in about fix Weeks 


\section{( 55 )}

' time they were all well rooted, and fit to rake off. Afterwards

' I took eight or nine Cuttings, at different times, and with a ' great deal of Care I got five of them to take Root very well.

- It would have been eafy for me to multiply thefe Experimenis,

' but as I was now Mafter of twelve Trees, I thought it unne-

: ceffary to give my felf any farther Trouble, at that time, and

$\therefore$ I have not had fo good an Opportunity fince.

'In raifing thefe Trees I ufed to give them frequent Water-

' ings, tho' but littlz at a time, and the Water being always well

' temper'd by ftanding a Day or two in a Stove beforehand:

- This laft I was particularly cautious about during the Winter.

- I found by Experiment likewife, that this Tree ought by no

- means to have the Ends of the Shoots cut or fhortened; all

- the pruning it will bear is to have its lowermoft Branches lope

' off clofe to the Trunk.

"Another Caution neceffary to be obferv'd, is to wafl the

- Leaves often; for by long ftanding in the Houfe they contract

- a Duft, and befides are very fubject to a particular Sort of In-

- fect that foils them, and prejudices the young Shoots, which

" generally lying on the under Side of the Leaf, may have done

' a great deal of Mifchief before they are obferv'd, except we be

c apprifed of them beforehand. They feem peculiar to the Cof-

: fee Leaves, for I never found them on any other Plant.

\section{.}

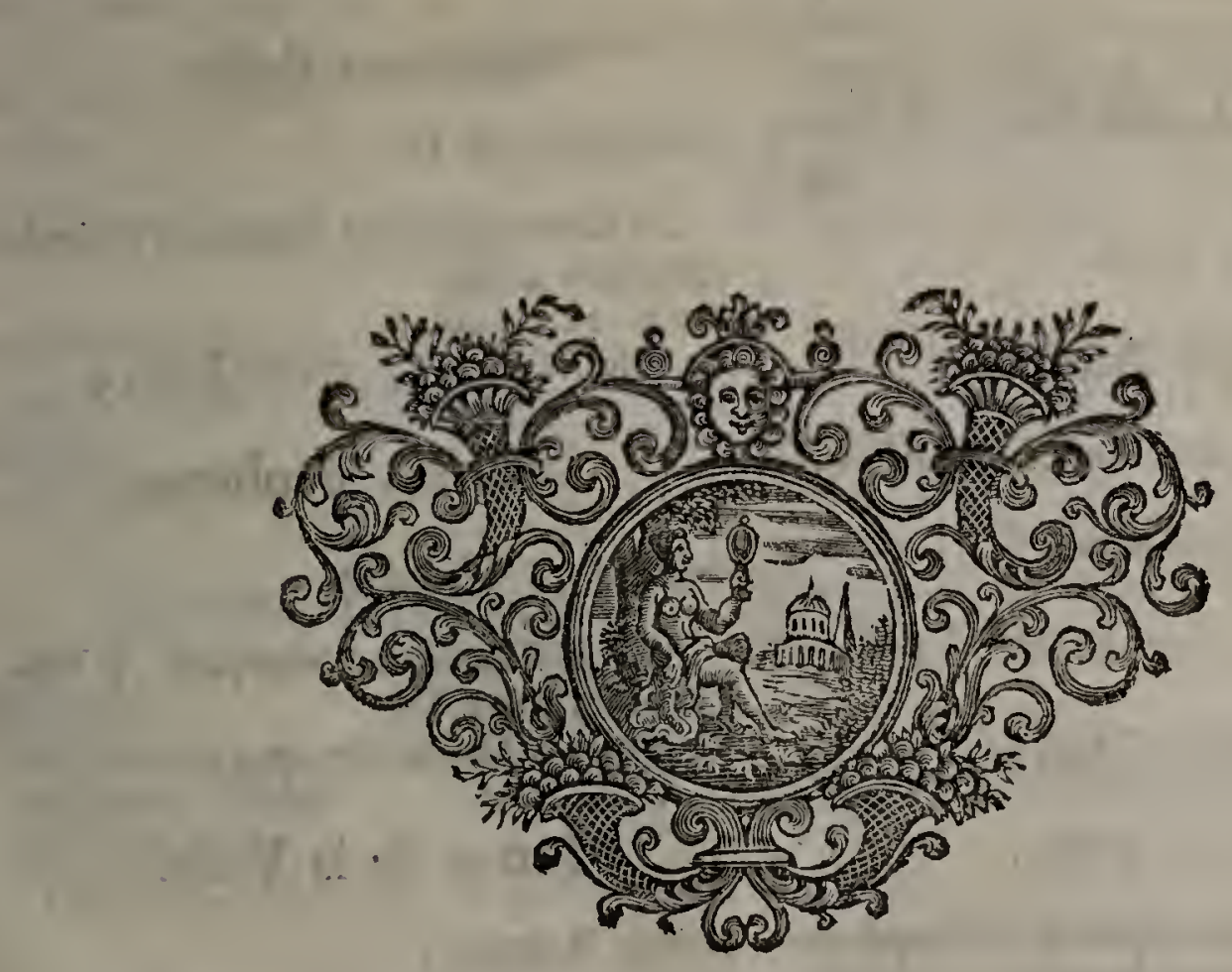

I N DE X 


\section{$(56)$}

A

\section{CATALOGUE of all the AUTHORs mentioned in this TREATISE.}

\section{A Bubeter Rhazes.}

Medicus Arabs. Ob.932.

Ad Regem Manforem Libri deccm, Latinitate donati.

Bafil. I 544. fol.

V. Lib. 3. c.22. p. 74 .

\section{Avicenna.}

Medicus Arabs. Ob. 1036 .

Liber Cannonis.

Bafil. I 556 . fol.

V. Lib. 2. Traet. 2. c. 91. p. 198. \& c. 82 . p. 196.

\section{Leonhartus Rauwolfius.}

Medicus Auguftanus.

Itinerarium Orientis.

Lugd. I $583.4^{\circ}$

An Itinerary into the Eaftern Countries. Tranlated from the High Dutch, by Nicolas Staphorft.

Lond. I 693. 8.

Vid. Part I. c. 8. p. 92.

\section{Profper Alpinus.}

Italus, Botanices, \&c. Profeffor Patavinus.

De Plantis Egypti Liber.

Venet. I592. 4 .

V. Edir. Perav. $1 \sigma_{40}$. 4. cap. 16. p. $\sigma_{3}$.

\section{Carolus Clufius.}

Atrebas. Botanicus illuftris.

Exoticorsm Liber Septimus five fimplicium aliguot medicamentorum apud Indos nafcentium biftoria, primum Lisfitanica lingua a D. Garcia ab Horto confcripta, deinde Latino Sermone contradt a Iconibus ơ Annotationibus illuftrata. Antwerp. IGox. fol.

V. Edit. Ibid. 1605 . fol. p. 236 . inter omnia Opera, Tom. 2.
Johannes Gerardus.

Anglus. Chirurgus Londinenfis:

The Herbal, or General. Hiftory of Plants; enlarged and amended, by Thomas Jonfon, Apotbecary,

Lond. I 597. fol.

V. Lib. 3. c. I50. p. I 548 .

\section{Johannes Cotovicus.}

Ultrajectinus. .

Iter Hierofolymitanum.

Ultraj. I 598.

\section{Bernardus Paludanus.}

M. D. Enchufanus.

Note in Linfchottum.

Amftelod. I 599.

\section{Honorius Bellus.}

Vicentinus. M.D.

Ad Carolum Clufium Epifole de rarioribus guibufdam plantis.

Antw. r6or. fol.

V. Cluf. Tom. I. p. cccix. Epift. 4.

Johannes Bauhinus.

Bafilienfis. Ob. 1613 .

Hiftoria Plantarsm Univerfalis $3 \mathrm{Vol}$.

Ebrodun. 1650 . fol.

V. Tom. I. Lib. 4. c. 5. p. 421 .

Petrus de la Valle.

Nobilis Romanus.

Les Famenx Voyages en Turquie, Egypte, La Paleftine, la Perfe, eóc.

Paris, 1670.4 to. 4 Vol.

V. Vol. I. p. 53,78 .

Epift. dat $x$ Conftantinop. An, 1615, I 616.

D. GAR - 


\section{( 57 )}

\section{Garcias Silva Figuerva.}

\section{Hifpanus.}

L'Ambajfade en Perfe traduite deL'Efpagnole par M. de Wigfort.

Paris, I 66 I. 4 to.

V. p. 3.07 .

Legat. incopta Ann. $1 \sigma_{17}$. finit. $1 \sigma_{24}$.

\section{Calparus Bauhinus.}

Bafilienfis. Botanicus fummus.

Miva Theatri Botanici.

Bafil. I623. 4 to.

V. Edit. Ibid. 167 1. lib. 2. fect. 5. p. 428 .

\section{Georgius Sandys.}

Anglus.

$A$ Relation of a Fourney begun in 1610. In four Books, containing a Relation of the Turkifh Empire.

Lond. 1627. fol.

V. p. 66 .

\section{Adamus Olearius.}

\section{Germanus.}

Voyages faits en Mofcovie, Tartarie et en Perfe traduits de L'Allemande ct Augmentez par le Sieur de Wugfort.

I.ugd. Barav. I 7 19. fol.

V. Vol. 2. p. 833 .

Iter Incopt. $1633^{3}$ Edit. primo. Anno 1644 .

\section{Thomas Johnfon.}

Anglus Pharmacopolus \& M. D.

Geiard's Hiffory of Plants enlarged and corrected.

Lond. $I_{3} \sigma$. fol.

\section{Johannes Veflingius.}

\section{Mindanus.}

De Plantis Egypti Obfervationes \& Note in Profperum Alpinum.

Petav. I638. $4^{\text {to. }}$

V. Edit. ibid. I $6_{40}$. cap. I 6. p. $\sigma_{3}$.

\section{Johannes Parkinfon.}

Anglus. Pharmacop. Reg.

The Theatre of Plants, or an nxiverfal and complcat Herbal.

Lond. I 640. fol.

V. Tribe I7. c. 79. p. 1622.

\section{Gualcherus Rumfey.}

Anglus.

Organon Salutis, ax Inftrument to cleanfe the Stomach; as alfo divers Experiments touching the Virtues of Coffee and Tobacco. Lond. 1657.

V. Edit. 1659. 12mo. p. 5, 9, 23, E3c.

Thevenot.

Gallus.

Travels into the Levant, in threc Parts; done into Engliih from the French.

Lond. I 687 . fol.

V. Part I. p. 32. Part 2. p. 180.

Reverfus eft circa 1660 .

\section{Laurentius Straufius.}

\section{Germanus.}

The Manner of making Coffee, Tea, and Chocolate; tranflated into Englifh.

Lond. I685. I $2 \mathrm{mo}$.

Edit. Latin. Circit. I 660.

\section{Simeon Pauli.}

Danus. M. D.

Commentarius de Abufis Thee of Tabaci.

Roftoch. 166I. 4.

Ouadripartitum Botanicum de Simplicium Medicamentorum facu?tatibus.

Argentor. 1667.410.

V. p. 370,396 , \&.c.

\section{Fauftus Naironus Banefius.}

\section{Maronita.}

De Saluberrima Potione Cabué feu Café nuncupata Difcurfus ad Eminentifimum Principem D. Fo. Nicol. Cardinalem de Comitibus.

Rom. I 67 r.

\section{Georgius Hieronymus Velfchius.}

Germanus. M. D.

Exercitatio de Vena Medinenza ad Mentem Ebufine.

Auguft. Vendelic. 1674. 4to.

V. Cap. I2. P. 328 .

\section{Dominicus Chabræus.}

Princip. Wirtimbergens. Medicus. 


\section{$\left(5^{8}\right)$}

Omnium Stirpitrm Sciographia \& Icones.

Genev. 1678 . fol.

V. Claf. 4. p.32. Claf. I2.p.90.

\section{Henricus Mundy.}

Anglus. M. D.

Broxpnsonoyize fiu Commentarii de Aere Vitali, Efculentis of Portulentis.

Oxon. I680. 8.

V. De Potul. c. 14. p. 35 I.

\section{Nehemias Grew.}

Anglus. M. D.

The Anatomy of Plants.

Lond. 1682 . fol.

V. Lib. 4.c.3. p.202.c. 4. p. 206 .

\section{Thomas Willis.}

\section{Anglus. M. D.}

Pbarmacntice rationalis feu Diatriba de Medicamentorum opcrationibus.

Amftel. I682. 4to. Edit. Ima. 1674 .

V. lect. 7• c. 3• p. 129 .

\section{Johannes Baptifta Tavernier.}

Gallus. Chevalier Baron d'Aubonne.

Les fix Voyages qu'il a fait en Turquie on

Perfe of aux Indes pendant C'efpace de quarante ans.

Paris, I682. 3 Vol. . 4 to.

V. Vol. I. Lib. s. c. 17. p. $580,582$.

\section{Bernier.}

Gallus. M.D.

Lettre fur le Caffé ecrite a $M$. Du Four.

V. Du Four, p. 207 .

\section{Philippus Silvefter Du Four.}

Gallus. Mercator Lugdunenfis.

Traittez Nouveaux of Curienx du Caffé du Thé, \& du Chocolate.

Lugd. 1683.

V. Edit. I688. a p. 1. ad 216 .

\section{Nicolas Blegny.}

Gallus. M.D.

Le Bon ufage du Caffe', du The, of du Chocolate, pour la preforvation of pour la Gueri fon des Maladics.

Paris, 1687. 12.

\section{Tancredus Robinfon.}

Anglus. M. D.

Letter to Mr. Ray, dated May 21.1687. V. Philor. Letters between Mr. Ray and his Correfpondents, publinh'd by the Reverend Mr. Derbam.

Lond. $17 \mathrm{I} 8$. p. 207.

\section{Johannes Ray.}

Anglus. F. R.S.

Hiftoria Plantarum, Tomus fecundus.

Lond. 1688. fol.

V. p. $169 \mathrm{r}$.

\section{Cornelius Bontekoe.}

Batavus. M. D.

Tractaat Van bet Excellenfte krisyd The Coffi en Chocolate.

Amftel. I689. 4to.

V. p. $107, \&$ c.

\section{Claudius Salmafius.}

\section{Gallus.}

De Homonymis Hyles Iatrice: Traject. ad Rhen. 1689 . fol.

V. c. 78 . p. ro6.

Jjoh. Jacobus Berlı.

The Treafury of Drugs unlock'd.

Lond. I 693 .

V. Edit. 1724 . I 2 mo. p. I7.

\section{Gulielmus Salmon.}

Anglus. M. D.

Seplafium. The Compleat Englifh Pbyfician; or, Druggift's Shop open'd.

Lond. 1693.8 .

V. Lib. 8 . c. s. p. 858 .

\section{Thom. Pope Blount.}

Anglus Eques Auratus.

A Natural Hiftory, containing many not: common Obfervations.

Lond. 1693.8.

V. p. 107 . 
Johannes Pechey.

Anglus. M. D.

The Compleat Herbal of Physical Plants. Lond. 1694.8.

V. p. 243 .

\section{Petrus Pomet.}

Gallus Aromatarius Parifienfis.

Hiftoire Generale des drogucs.

Paris, 1694. fol.

V. Lib.7. p. 204.

\section{Hans Sloane.}

M. D. Eq. Aurat. Collegii Med. Lond. \& Gallus.

R.S. Præres digniffimus.

An Account of the Coffee Shrub.

Lond. 1694. 4 .

V. Philof. Tranfact. No 208. p. 6 I.

\section{Paulus Hermannus.}

Saxo-Germanus. M. D.

Cynofura Materic Medice.

Argentor. 17 10. 4 .

V. Part I. C. 5. P. I 57 .

\section{Galand.}

Gallus. Lingux Arabicx Profeffor Regius.

V. Monf. la Roque.

\section{Jacobus Vanierus.}

Gallus. E Soc. Jefu.

Columbe of Vites five predium Rufticum.

Paris, 1606.8 .

V. Lib. 8. p. 1 56.

\section{Leonhardus Plunknet.}

Anglus. M. D.

Almajeftum Botanicum.

Lond. 1696 . fol.

\section{Nicolaus Lemery.}

Gallus. M. D.

Traitté Univerfelle des Drogues Simples.

Paris, 1698.4 to.

V. p. 129 .

\section{Cafparus Commelinus.}

Batavus Botanices Profeffor Amftxlædamenfis.

Catalogus Plantarum Ufualium Hor:i Amfteladamenfis.

Ainftel. 1698.8 .

\section{Johannes Houghton.}

- Anglus. F.R.S.

A Difcourfe of Coffce.

Lond. 1699. 4to.

V. Philof. Tranfact. No256. p. 3 II.

\section{Du Mont.}

Voyages en Turquie, \& $c$.

Hag. Com. 1699.8.

V. Vol.4. p. 7 I, \&c.

\section{Ludov. Lemery.}

Gallus. M. D.

A Treatife of Foods in general; tranlated from the French.

Lond. 1706. 8.

V. p. 3 I6. Edit. Gall. 1702:

\section{Chriftianus Johan. Langius.}

\section{Germanûs.}

Lectiones de Materia Medica.

Lipf. 1704. fol.

V. $\mathrm{p} \cdot 389$.

Joleph. Pitton Tournefort.

Aqui fextrenfis. M. D. \& Botanices Profeffor Parifienfis.

Traitté de la Matiere Mcdicale.

Paris, I7 I 7. 2 Vol. 8.

V. Vol.2. p. 98.

\section{Samuel Dale.}

Anglus. Pharmacopæus Brantrienfis.

Supplementum Pbarmacologie.

Lond. I 7 10. 8.

V. p. 49 r.

\section{Joh. Baptifta Chomel.}

Gallus. M.D.

Abrege de $L$ ' biftoire des plantes ufuelles.

Paris. 17 I2. 8 .

V. p. 243 .

Nicolaus 
$(60)$

\section{Nicolaus Andry}

Gallus. M.D.

Traitté des Alimens du Caréme, Paris, I7 I3. 2 Vol. 8 .

V. Vol. 2. p. 367 .

\section{Johannes Chriftophor. Volka-} merus.

Germanus. M. D.

Epiftola de Gelfemino Arabico, frultum Cafe ferente Arbore, data 17 I4.

V. Academ. Cærareo-Leopoldinæ Ephem. Cent. 4. Obf. 168. p. 378.

Noriberg. I7 Is. 4 .

\section{Richardus Bradley.}

Anglus. Botan. Prof. Cantab. R. S. S. A port biftorical Account of Coffee. Lond. I $2 \mathrm{mo}$.

New Improvements of Planting and Gar. dening.

Lond. 17 I 8.8.

V. Edir. 4. p. 389 .

The Virtuc and Ufe of Coffec, with regard to the Plague.

Ibid. 172 I. 8.

Montbly Treatifes of IIusbandry and Gardening.

Ibid. $1724 \cdot: 3$ Vol. 8

V. Vol. 3. July, p. 65. Augult, p. $16 \mathrm{i}$.

Appendix to the New Improvements in Planting , nd Gardening.

Ibid. 1726.8 .

V. p. 63,70 .

\section{Antonius de Juffieu.}

Gallus. Botan. Prof. Parifie 〔. celeberrimus. Hiftoire du Caf'e, An. I7 I5.

V. Memoires'de l'A cademie Royale, I 7 I 3 . Amftelod. 1717. 8. p. 388 .

\section{Fontenelle.}

Gallus, Acad. Reg. a Secretis. Obfervation Botanique.

V. Memoires de l'Academie, I 76 . Amftelod. I 7 19. p. 42 .

\section{La Roque.}

'Gallus.

Voyage de l'Arabie Heureufe, avec un memoire concernant l' Arbre Go le fruit du Café of un traite biflorique de l'Origine of du Progres du Cafi.

Amftel. 17 I 6.8 .

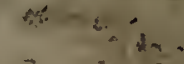

\section{Michael Bernardus Valentini.}

Archiarer Hefiacus \& Med. Prof. Gieffenfis.

Hiftoria Simplicium reformata.

Francof. ad...en. i7 i6. fol.

V. L. 2. Sect. 5. c. 2. p. 194 .

\section{Johannes Quincy:}

Anglus. M. D.

$A$ compleat Englinh Difpenfatory.

Lond. I 7 18. 8.

V. p. 83 .

\section{Hermannus Bocrhaave.}

Batavus. Med. Botan. \& Chem. Prof, Lugd. Batavus.

Index alier plantarsm que in Horto Lugduno Batavo aluntur.

Lugd. Bat. 1720.4

V. Part 2. p. II 7 .

\section{Jofephus Miller.}

Anglus, Pharmacopæus Londinenfis.

Botanicum officinale; or, a compendious Herbal.

Lond. 1722.8 .

V. p. I44.

\section{Georgius Cheyne.}

Scotus. M. D.

Tractatus de Infirmorum fanitate tuendd, vitaque producenda.

Lond. 1726.8.

V. p. 86,87 . 


(n)

SAnAh

hand

(A)

a

âtanant

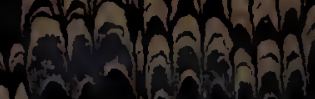

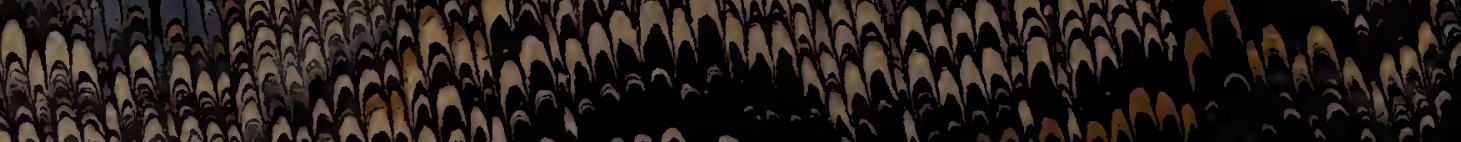

A Th

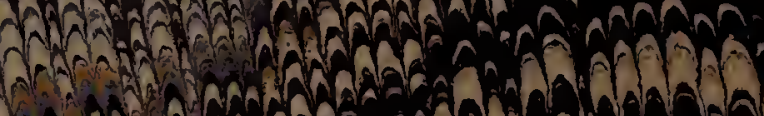

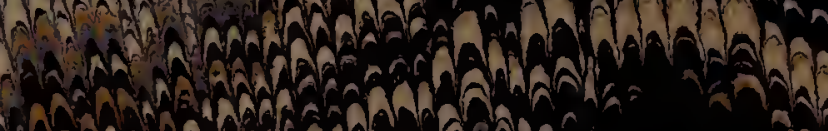

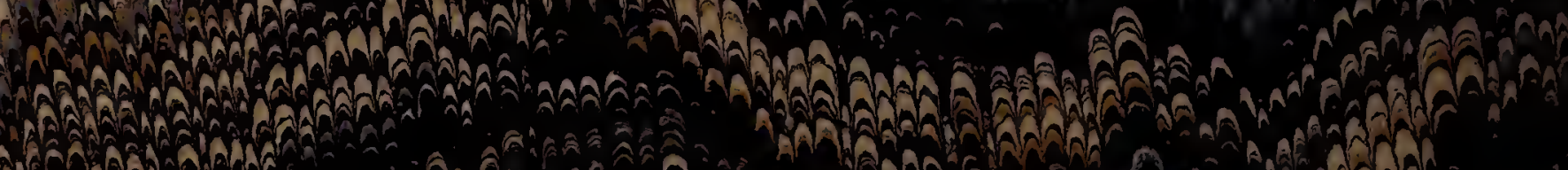

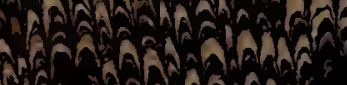

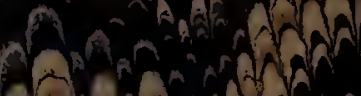

Hinn

AnTANAS

ât

Honan anana

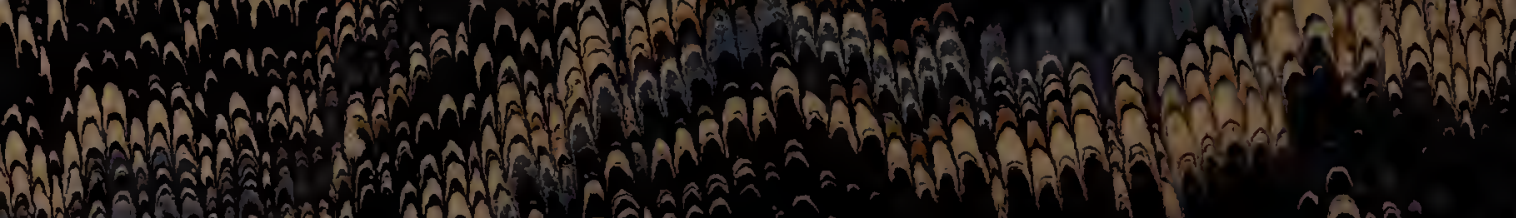

And

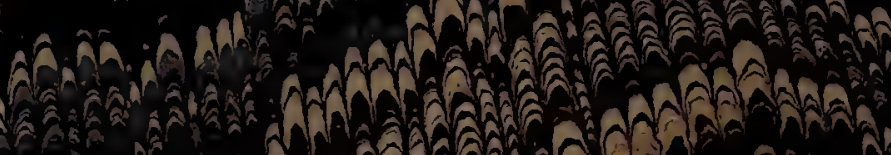

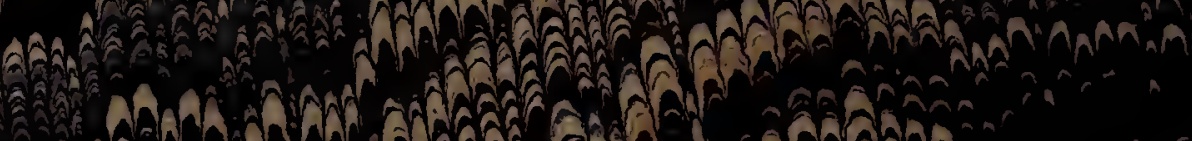

chañ

(n)

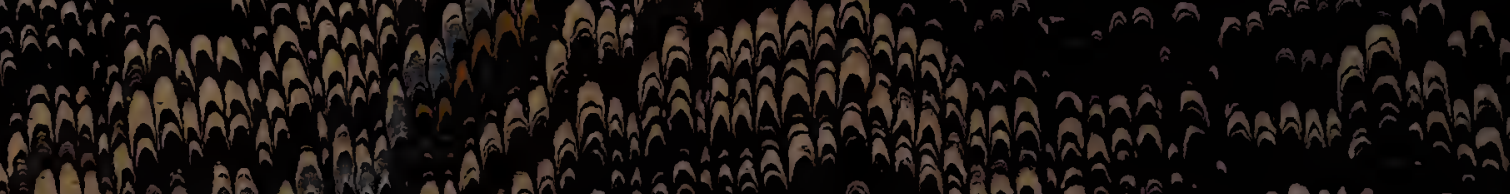

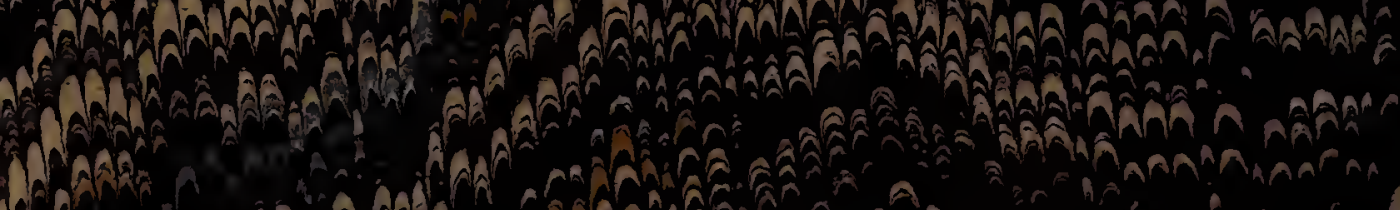

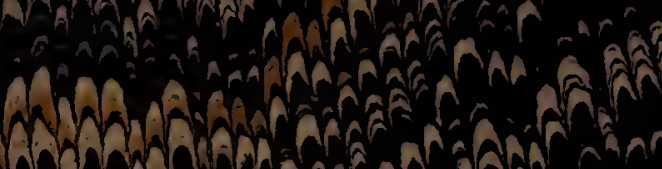

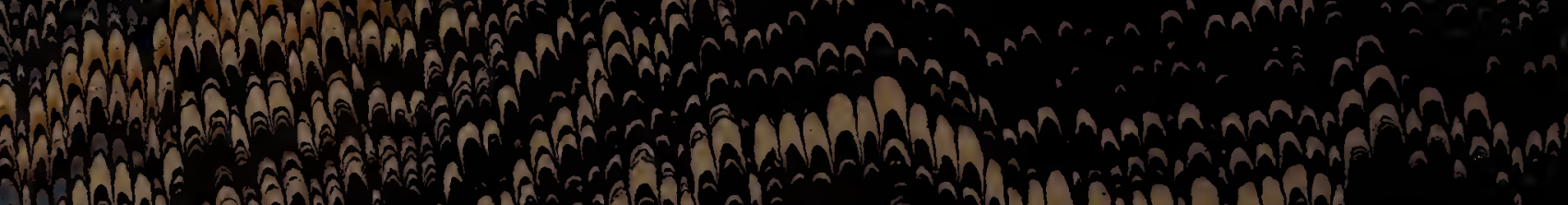

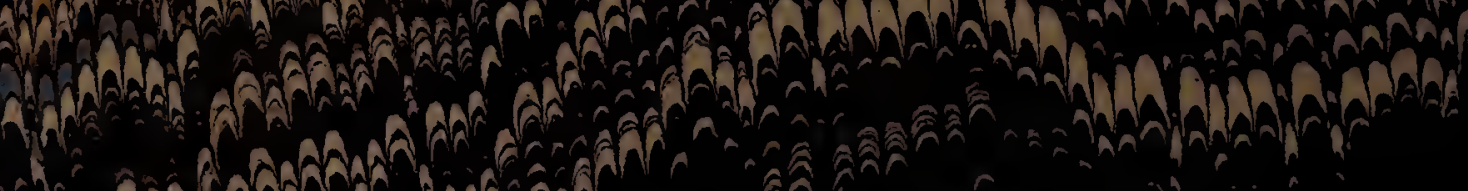

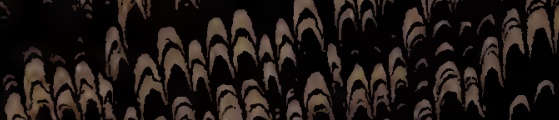

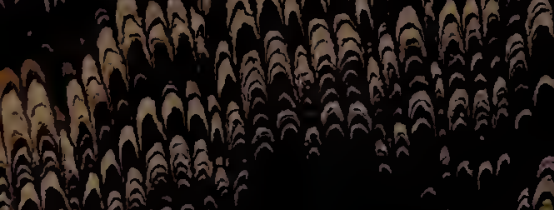

a

ân

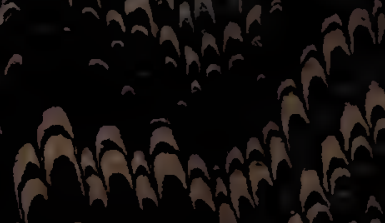

whin

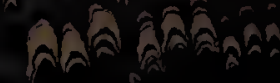


ลิล

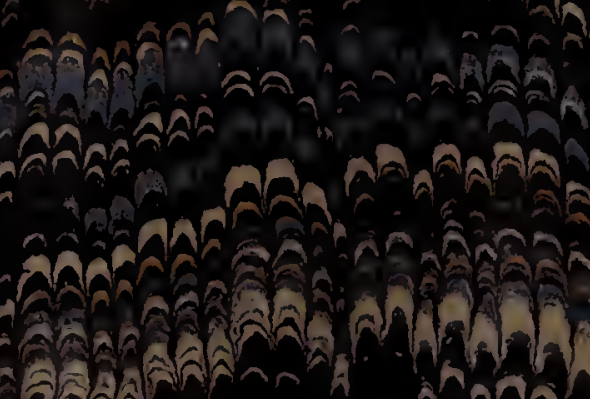

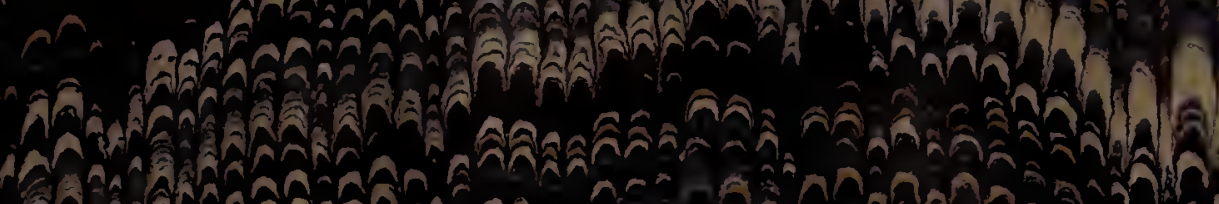

*

Whin

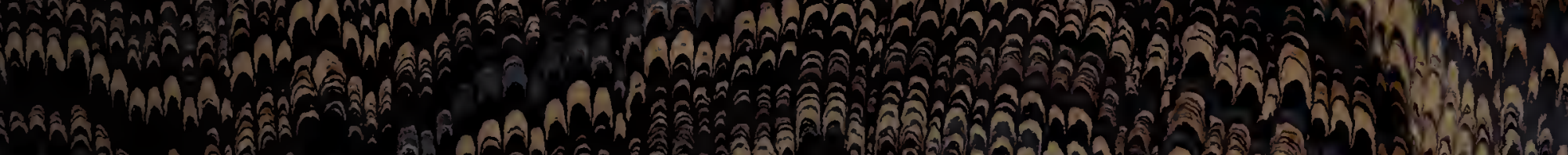
- A A A H A

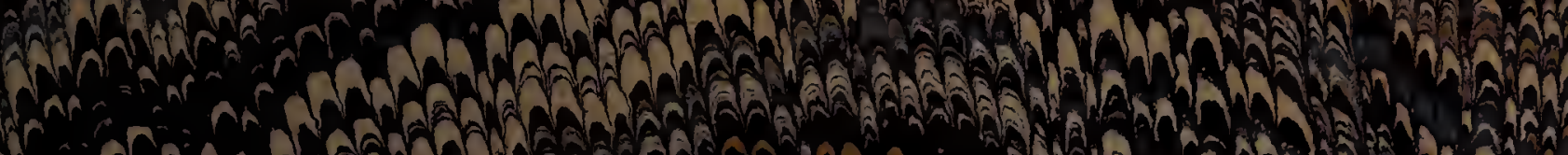

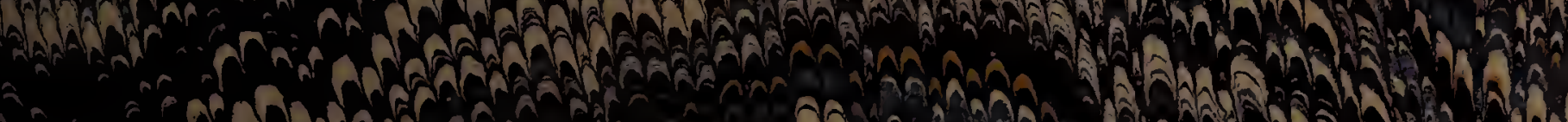
cranchench

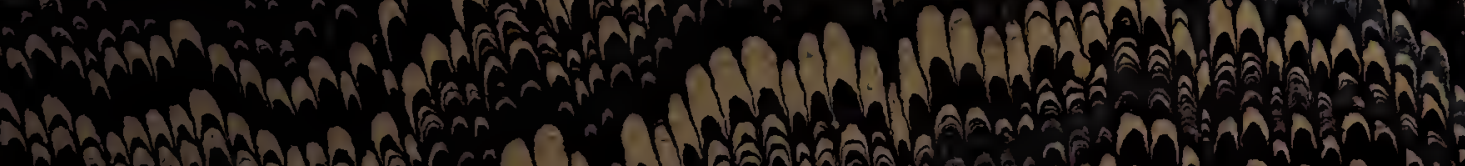

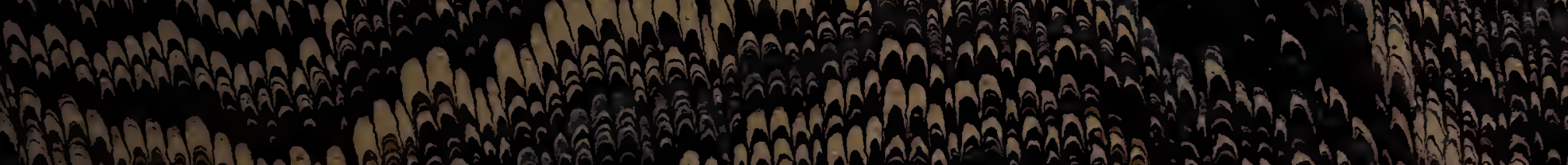
Whand 12Han

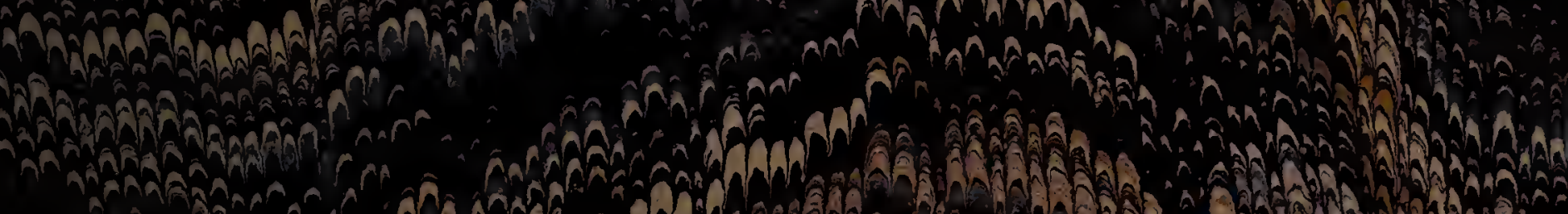
Anno

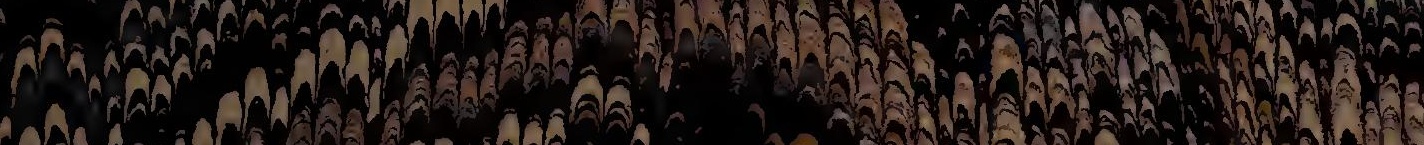
(6) GA

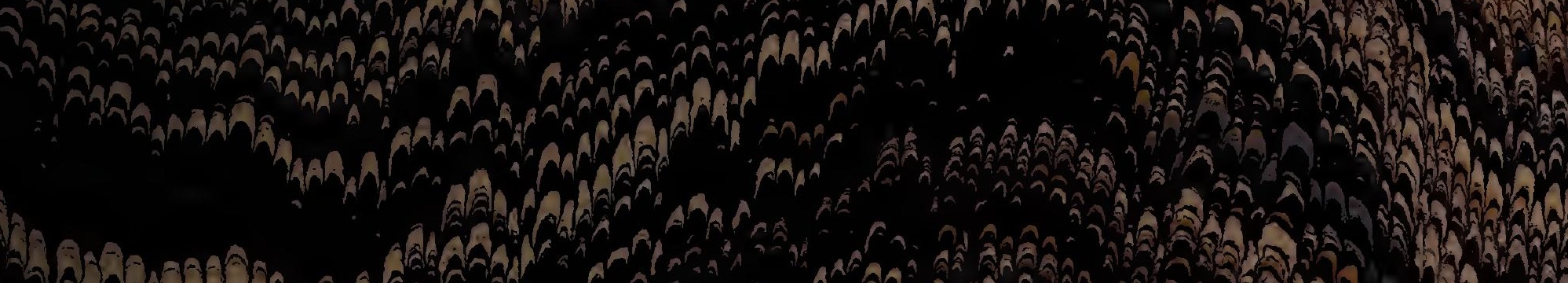
คคำ

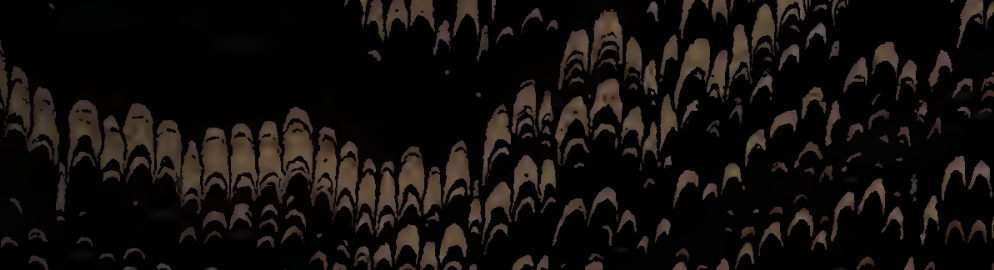

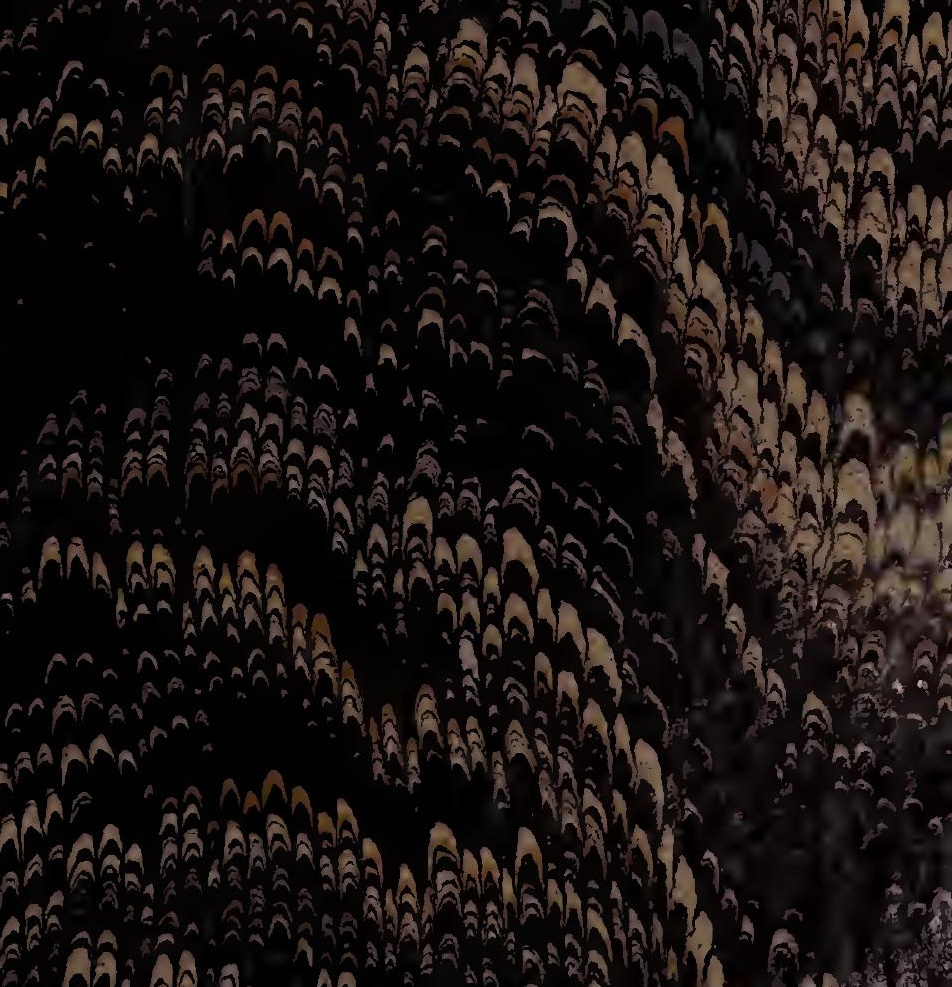


